\title{
Peptides and the Primary Afferent Nociceptor
}

\author{
Jon D. Levine, ${ }^{1,2,3}$ Howard L. Fields, ${ }^{4,5}$ and Allan I. Basbaum ${ }^{2,4}$ \\ Departments of ${ }^{1}$ Medicine, ${ }^{2}$ Anatomy, ${ }^{3}$ Oral Surgery, ${ }^{4}$ Physiology, and ${ }^{5}$ Neurology, and Keck Center for Integrative \\ Neuroscience, University of California at San Francisco, San Francisco, California 94143
}

Animal tissues are innervated by sensory neurons that respond with increasing discharge frequency to stimuli that have the potential to cause tissue damage. In vertebrates these neurons are called primary afferent nociceptors (PANs); they have their cell bodies [dorsal root ganglion (DRG) ncurons] in sensory ganglia and a central process that connects synaptically to sensory transmission neurons in the CNS. It is now clear that the PAN does more than simply relay information about intense thermal, mechanical, and chemical stimuli; rather, the PAN is subject to modulation at its central and peripheral terminals, has a peripheral neuroeffector function, and undergoes activitydependent long-term changes. This expanded view of the function of the PAN has resulted, in part, from a more comprehensive description of the peptides contained in PANs and of their functions. This article focuses on the role of neuropeptides in PAN function.

\section{Activation and sensitization of primary afferent nociceptors}

Activation

Activation of the PAN at its peripheral terminal requircs intense mechanical, thermal, or chemical stimulation. Although the concentration of many endogenous chemicals that can activate PANs (e.g., 5-HT, histamine, and hydrogen and potassium ions) increases in an area of tissue damage, among the peptides that do so, only bradykinin (BK) has been extensively studied (Kumazawa et al., 1991). Bradykinin is a nonapeptide (Arg-ProPro-Gly-Phe-Ser-Pro-Phe-Arg) cleaved by enzymes (kallikreins) from certain proteins that circulate in the plasma. Kallikreins are rapidly activated at sites of tissue injury, leading to the local production of large amounts of BK (Garrison, 1990). There are two known types of $B K$ receptor $\left(B_{1}\right.$ and $\left.B_{2}\right)$. Activation of PANs by $B K$ is mimicked by $B_{2}$ - but not $B_{1}$-type agonists and is selectively antagonized by $B_{2}$ antagonists (Dray and Perkins, 1988; Haley et al., 1989; Kumazawa et al., 1991). Similarly, BK-induced pain in humans appears to be mediated

Key words: spinal cord, inflammation, substance $P$, CGRP, pain, hyperalgesia, opioid, analgesia

This work was supported by NIH Grants DA-01949, NS-21445, NS-21647, DE-08973, and AM-32634, Grants DE/NIDA-08973 and NS-14627, and a grant from Bristol-Meyers Squibb.

Correspondence should be addressed to Howard L. Fields, M.D., Ph.D., Box 0114, Department of Neurology, University of California, San Francisco, CA 94143.

Copyright (c) 1993 Society for Neuroscience $0270-6474 / 93 / 132273-14 \$ 05.00 / 0$ by the $\mathrm{B}_{2}$-type receptor (Whalley et al., 1989). BK-induced activation of PANs involves the generation of diacyl glycerol and activation of protein kinase $\mathrm{C}$, leading to an increase in a sodium conductance (Dray et al., 1988; Burgess et al., 1989; but see Dunn and Rang, 1990). Although tachyphylaxis develops rapidly when BK is repeatedly applied (Kumazawa et al., 1991), other inflammatory mediators can prolong $\mathrm{BK}$ activation of PANs (King et al., 1976; Kirchhoff et al., 1990; Lang et al., 1990).

\section{Direct sensitization}

In contrast to the constant stimulus-response function for many sensory receptors, repeated noxious stimulation or tissue damage produces prolonged increases in PAN excitability. This phenomenon, termed sensitization, is manifested by an increase in spontaneous activity, a lowered threshold for activation, and increased and prolonged firing to a suprathreshold stimulus (Meyer and Campbell, 1981; LaMotte et al., 1982, 1983). Sensitization of PANs contributes to hyperalgesia, which is defined as a lowered threshold for evoking behavioral indicators of pain in animals and the tenderness that is associated with inflammation in humans.

Several endogenous peptides generated at a site of injury or inflammation can sensitize PANs directly. These include interleukin-1 (IL-1), neutrophil-chemotactic peptides, and NGFoctapeptide (NGF-OP). Because of the clinical importance of hyperalgesia, the identity and mechanisms of action of hyperalgesic mediators is a major area of interest. The technique currently used to study direct sensitization involves cultured DRG neurons. These can be identified as probable nociceptors if they are depolarized by capsaicin (a nonpeptide pain-producing ingredient in chili peppers), which in vivo predominantly activates nociceptive small-diameter primary afferents (Helme et al., 1986; Jonsson et al., 1986; Saria et al., 1988; Lynn, 1990). Nonpeptide agents that directly sensitize PANs include prostaglandin $E_{2}$, prostaglandin $I_{2}$, the lipoxygenase product of arachidonic acid, $8 R, 15 S$-diHETE (Taiwo et al., 1987), adenosine [acting at an $\mathrm{A}_{2}$-type receptor (Taiwo and Levine, 1990)], and 5-HT [acting at a 5-HT $\mathrm{H}_{\mathrm{a}}$ receptor (Taiwo and Levine, 1992)]. Prostaglandin $\mathrm{E}_{2}$ has recently been shown to increase the calcium conductance and to stimulate the release of peptide transmitter from cultured DRG cells (Nicol et al., 1992).

\section{Indirect sensitization}

Both neural and non-neural cellular elements are required for a variety of peptide mediators to act upon PANs. Thus, in contrast to hyperalgesic prostaglandins (prostaglandin $E_{2}$ and 
$\mathrm{I}_{2}$ ), which appear to sensitize PANs directly (Pitchford and Levine, 1991), most hyperalgesic peptides act on cells other than the PANs; these cells (e.g., sympathetic postganglionic neurons and white blood cells), in turn, release a hyperalgesic agent that acts directly on the PAN.

Bradykinin. Although BK activates PANs directly, BK-induced sensitization of PANs to mechanical stimuli is largely indirect and depends on prostaglandin synthesis (Lembeck et al., 1976; Gonzales et al., 1989; Kumazawa et al., 1991). BK hyperalgesia is blocked by the prostaglandin $E_{2}$ receptor antagonist SC19220 (Taiwo and Levine, 1988). Furthermore, there is evidence that BK-induced hyperalgesia to mechanical stimuli depends on sympathetic postglanglionic neuron (SPGN) terminals; it is markedly attenuated by their chemical destruction with 6-hydroxydopamine (Levine et al., 1986c). BK-induced hyperalgesia is also blocked by mepacrine (a phospholipase $\mathrm{A}_{2}$ antagonist), suggesting that $\mathrm{BK}$-induced production of the directly acting hyperalgesic agent prostaglandin $E_{2}$ is a phospholipase $A_{2}$-dependent activity (Taiwo et al., 1990).

BK sensitizes PANs to thermal as well as mechanical stimuli in animals, and in humans produces thermal hyperalgesia (Raja et al., 1990). The duration of the sensitization to thermal stimuli is relatively brief (Koltzenburg et al., 1991; Kumazawa et al., 1991) and is blocked by prostaglandin synthesis inhibitors (Kumazawa et al., 1991). In contrast to BK-induced mechanical hyperalgesia, Koltzenburg et al. (1991) reported that BK-induced sensitization to thermal stimuli is not attenuated by surgical sympathectomy. Although this suggests a direct BK effect on PANs, surgical sympathectomy is less complete than chemical sympathectomy produced by 6-hydroxydopamine (Fischer et al., 1964; Thoenen, 1972).

Interleukin-1. IL-1 refers to two polypeptides (IL-1 $\alpha$ and IL$1 \beta$ ), classified as cytokines, that stimulate proliferation of and protein synthesis in a variety of cells (Dinarello, 1989). Cytokines are produced by leukocytes and other cells in response to infection, exposure to bacterial toxins, and inflammatory mediators. IL- $1 \beta$ is a potent hyperalgesic agent with a probable peripheral site of action (Ferreira et al., 1988). Interestingly, a tripeptide analog of IL-1 $\beta$ acts as a peripherally acting analgesic. This tripeptide blocks hyperalgesia induced by both IL- $1 \beta$ and carrageenan, a proinflammatory plant polysaccharide. Since IL-1 induces E-type prostaglandin production in non-neuronal cells (Dayer et al., 1986), it is not surprising that the prostaglandin synthesis inhibitor indomethacin inhibits IL-1 $\beta$ hyperalgesia.

Chemotactic peptides. There are two major pathways of arachidonic acid metabolism: the cyclooxygenase pathway, which leads to the production of prostaglandins, and the lipoxygenase pathway, which produces leukotrienes (Lewis, 1989). Metabolites of both pathways sensitize nociceptors. Although these compounds are not peptides, studies of their actions have led to the discovery of a novel class of hyperalgesic peptides, name$1 y$, those that attract and activate white blood cells.

Leukotriene $\mathrm{B}_{4}\left(\mathrm{LTB}_{4}\right)$ sensitizes PANs and produces hyperalgesia in animals (Rackham and Ford-Hutchinson, 1983; Levine et al., 1984a, 1985b, 1986b; Martin et al., 1988; Madison et al., 1992), and produces a tender and indurated lesion after intradermal injection in humans (Soter et al., 1983; Lewis et al., 1984). $\mathrm{LTB}_{4}$-induced hyperalgesia is distinguished from that induced by prostaglandin $\mathrm{E}_{2}$ and $\mathrm{BK}$ by its dependence on white blood cells and its independence of the SPGN and of the cyclooxygenation of arachidonic acid (Levine et al., 1984a, 1985b). The hyperalgesic factor released by white blood cells in response to $\mathrm{LTB}_{4}$ has been identified as $8 R, 15 S$-diHETE, another lipoxygenase product (Levine et al., 1986b). The hyperalgesic peptides that activate white blood cells include formyl Met-LeuPhe, a tripeptide generated during the degradation of bacterial cell wall proteins, and $\mathrm{C}_{5 \mathrm{a}}$, a fragment of the fifth component of the complement cascade.

Nerve growth factor-derived octapeptide. Cleavage of the amino-terminal end of NGF produces an octapeptide (NGF-OP: Ser-Ser-Thr-His-Pro-Val-Phe-His; Burton et al., 1978). Since enzyme inhibition studies indicated structural relatedness of NGF-OP and BK, we examined NGF-OP in nociceptive tests. NGF-OP produces a behavioral hyperalgesia that is dose dependent (Taiwo et al., 1991). Like BK-induced hyperalgesia, sympathectomy or indomethacin pretreatment attenuates NGFOP hyperalgesia. NGF-OP action, however, is distinct from that of BK. NGF-OP induces hyperalgesia only in the setting of tissue injury. Since NGF production is markedly increased after nerve injury (Heumann et al., 1987a), it is possible that NGF-OP contributes to the pain and hyperalgesia associated with nerve injury. NGF gene expression (Heumann et al., 1987b; Lindholm et al., 1987) can also be enhanced by IL-1, the hyperalgesic cytokine mentioned above.

In summary, tissue damage or inflammation generate mediators, including peptides, that produce a prolonged lowering of the PAN threshold. Importantly, the lowering of PAN threshold depends on the presence of cells other than the PAN such as white blood cells and SPGNs. Thus, these cells must play a crucial role in the sensory transduction process. Analgesic and anti-inflammatory drugs such as aspirin and indomethacin block the generation of these mediators. The development of receptor blockers for these peptide mediators represents an important avenue for development of new analgesic agents.

\section{Modulation of the peripheral terminals of primary afferent nociceptors by opioids}

In addition to their well-characterized antinociceptive actions in the CNS (see below), opioids act in the periphery to modulate PAN function (Basbaum and Levine, 1991). Opioid binding sites, synthesized in the DRG, are transported into the peripheral, as well as the central, terminals of sensory neurons (Young et al., 1980; Laduron, 1984). Indeed, local injection of opioids into inflamed tissue reduces activity in PANs (Russell et al., 1987). Behavioral studies demonstrated a naloxone-antagonizable analgesic effect of opioids directly injected into tissue that is injured or inflamed (i.e., hyperalgesic) (Ferreira and Nakamura, 1979; Abbott, 1988; Levine and Taiwo, 1989; Stein et al., 1989) but not after injection into normal tissue (Hargreaves et al., 1987; Russell et al., 1987; Smith et al., 1988; Stein et al., 1988,1989 ). In a recent clinical trial using injection of opioids directly into the knee joint, Stein et al. (1991) provided evidence that a peripheral action of opioids may relieve pain in patients following knee surgery.

Of the three major classes of opioid receptor ligands $(\mu, \delta, \kappa)$, $\mu$-ligands appear to be the most potent of the peripherally acting agonists (Joris et al., 1987; Levine and Taiwo, 1989; Stein et al., 1989). $\mu$-Receptor-specific agonists appear to act on the terminals of the PAN (Taiwo and Levine, 1991a). Thus, intradermal injection of DAMGO, a $\mu$-opioid receptor-selective agonist, but neither the $\delta$-selective ligand DPDPE nor the $\kappa$-selective ligand $U 50,488 \mathrm{H}$, inhibits the hyperalgesia induced by prostaglandin $E_{2}$ (Levine and Taiwo, 1989). The analgesic effect of the peripherally administered $\mu$-ligand is prevented by per- 


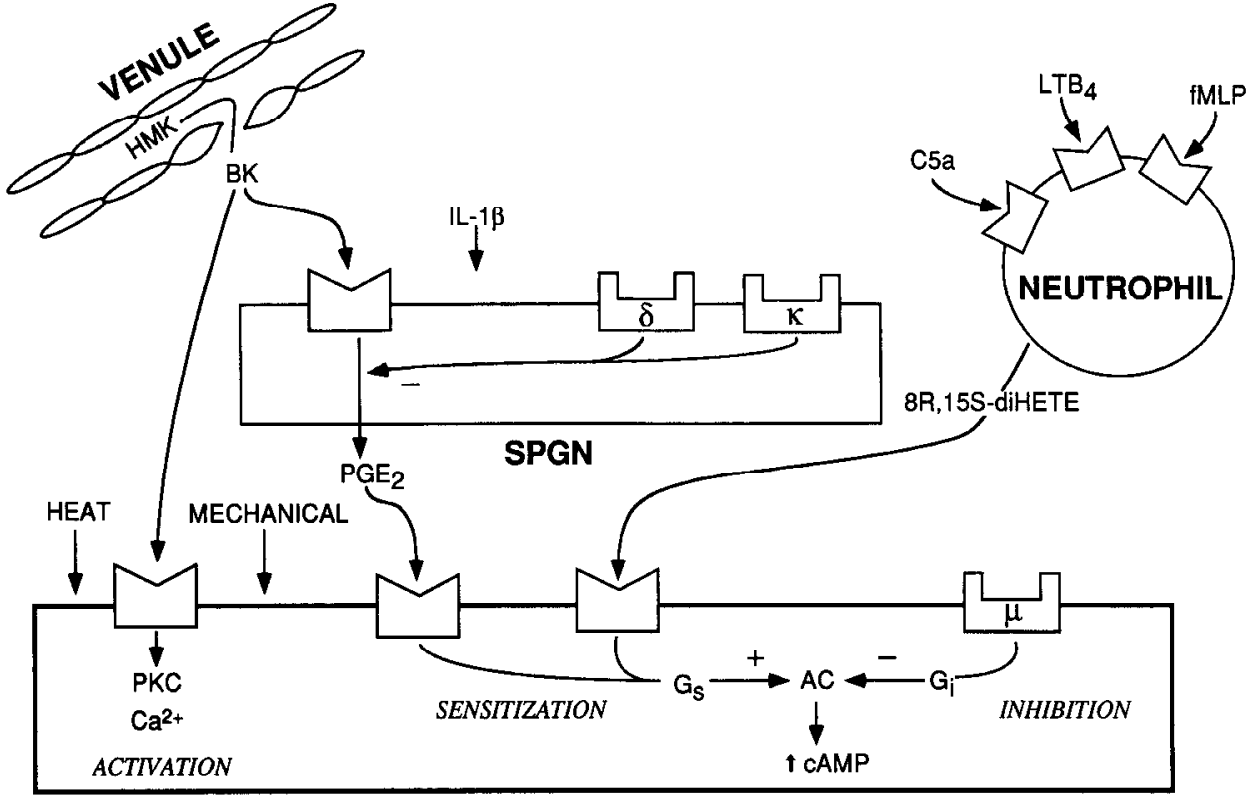

PRIMARY AFFERENT NOCICEPTOR
Figure 1. Sites of peptide action in peripheral pathways of pain and hyperalgesia. The inflammatory peptide bradykinin $(B K)$, cleaved from highmolecular-weight kininogen ( $H M K$ ) circulating in the venules, can activate the primary afferent nociceptor (PAN) in a protein kinase $\mathrm{C}(\mathrm{PKC})$ - and $\mathrm{Ca}^{2+}$ dependent mechanism or sensitize the PAN through the production of $P G E_{2}$ in sympathetic postganglionic neurons $(S P G N)$. Interleukin-1 $\beta(I L-1 \beta)$ also can sensitize the primary afferent through a similar mechanism. The chemotactic peptides $C_{s a}$ and $f M L P$ activate the neutrophil, as does leukotriene $B_{4}$ $\left(L T B_{4}\right)$, and causes the release of the lipoxygenase product $8 R, 15 S-d H E T E$, which sensitizes the primary afferent directly. Primary afferent sensitization probably involves a stimulatory G-protein $\left(G_{s}\right)$ and the $C A M P$ second messenger system. Opioid ligands of the $\delta$ - and $\kappa$-classes can inhibit this sensitization at the level of the SPGN, and the $\mu$-class opioid ligand can do so at the level of the PAN via an inhibitory G-protein $\left(G_{i}\right)$. tussis toxin, suggesting that the effect is mediated by G-proteincoupled inhibition of cAMP. $\kappa$ - and $\delta$-ligands, which do not block prostaglandin $\mathrm{E}_{2}$-induced hyperalgesia, block BK-induced hyperalgesia (Taiwo and Levine, 1991b). Since $\kappa$ - and $\delta$-opioid receptors are located on SPGN terminals (Illes et al., 1980a,b, 1985; Hughes, 1981; Wuster et al., 1981; Berzetei et al., 1987, 1988), and since BK hyperalgesia depends on SPGN terminals, it is likely that $\delta$ - and $k$-ligands reduce the hyperalgesia through an action on the sympathetic terminals (see Fig. 1).

Receptors on the peripheral terminals of nerves may, of course, respond to endogenous as well as exogenous opioids, including those arising in the pituitary, adrenal cortex, and/or local inflammatory cells, specifically lymphocytes, which synthesize (Zurawski et al., 1986; Rosen et al., 1989) and release (Smith et al., 1986; Kavelaars et al., 1989) opioid peptides (Stein et al., 1990).

Figure 1 schematically illustrates our current understanding of the peripheral sites and mechanisms of action of peptides in pain and hyperalgesia.

\section{Peptides in primary afferent nociceptors}

\section{Distribution of peptides in dorsal root ganglion neurons}

The list of peptides found in primary afferents is large and growing. The most extensively studied primary afferent neuropeptide is substance $P(\mathrm{SP})$, an undecapeptide that is present in about $20 \%$ of DRG neurons. SP is a member of a family of peptides, the tachykinins or neurokinins, which have a common C-terminal amino acid sequence. Despite intensive study, it has not been shown that the release of SP, or for that matter of any individual peptide, is correlated with the activity of a single physiologically defined class of primary afferents. Thus, although SP is present in some PANs (Leah et al., 1985; Cameron et al., 1988; Plenderleith et al., 1990), it is not restricted to nociceptors. In fact, the identification of a specific peptide with a specific physiological class of sensory receptor is unlikely in view of the coexistence, in various combinations, of up to four peptides in single DRG neurons (Cameron et al., 1988). For example, up to $80 \%$ of SP-containing DRG neurons in the cat cocontain calcitonin gene-related peptide (CGRP; Garry et al., 1989); the fraction may be even higher in the rat (WiesenfeldHallin et al., 1984). Almost $26 \%$ of the SP-containing neurons also contain somatostatin (SOM); $34 \%$ of the SOM neurons contain SP and $22 \%$ of the SOM-containing neurons also contain CGRP. Furthermore, the pattern of peptide content is developmentally regulated (Hammond and Ruda, 1991), and the coexistence pattern differs considerably among species. Thus, SOM and SP appear not to coexist in the rat (Tuchscherer and Seybold, 1985). Furthermore, a significant fraction of smalldiameter DRG neurons contain neither SP nor SOM.

Although the complement of neuropeptides in primary afferent neurons does not correlate well with cutaneous sensory modality (Wall and Fitzgerald, 1982; Leah et al., 1985; see below), it may be related to the type of tissue innervated (Green and Dockray, 1987; McMahon and Gibson, 1987; Molander et al., 1987; Ositelu et al., 1987; O'Brien et al., 1989). In general, DRG neurons that innervate visceral targets are enriched in SP and CGRP compared to those innervating the skin. For example, of the population of DRG neurons that innervates the rat stomach antrum, up to $85 \%$ contain CGRP and up to $60 \%$ contain SP (Green and Dockray, 1988); this compares to $15 \%$ and $10 \%$, respectively, for DRG neurons that innervate the skin. When cutaneous nerves are cut and forced to reinnervate stomach antrum, the levels of SP and CGRP in the reinnervating DRG neurons increase significantly (Horgan and Van der Kooy, 1992).

\section{Plasticity in primary afferent nociceptors}

The concentrations of peptides in DRG neurons change after tissue injury or nerve damage. For example, hindlimb injection of formalin, which evokes a characteristic but short-lived pain syndrome, is associated with a significant increase in the number of DRG neurons expressing preprotachykinin (PPT) mRNA (Noguchi et al., 1988). In adjuvant-induced arthritis, the concentrations of SP and CGRP, but not SOM, are markedly increased in the DRG neurons that innervate the affected joints (Smith et al., 1992). On the other hand, Weihe et al. (1988) found little change in dorsal horn neurokinin immunoreactivity 
in response to inflammation (despite dramatic increases in the levels of dynorphin in second-order neurons of the dorsal horn). These changes in the DRG neurons outlast the pain behavior evoked by the same formalin stimulus.

In contrast to inflammation, sciatic nerve scction is associated with a decrease in the levels of PPT, CGRP, and SOM mRNA in DRG neurons (Noguchi et al., 1989, 1990); there is a corresponding decrease in the level of peptide immunoreactivity in terminals in the dorsal horn (Barbut et al., 1981). On the other hand, the levels of the peptides galanin and vasoactive intestinal peptide increase in DKG neurons after peripheral nerve section (Hökfelt et al., 1987; Noguchi et al., 1989). In part, this occurs in DRG neurons that previously expressed CGRP (Doughty et al., 1991). Neuropeptide Y mRNA and peptide, which are undetectable in DRG neurons of normal rats, rise to very high levels in rats with partial nerve section (Wakisaka et al., 1991). Taken together, these results indicate that nerve injury can alter the phenotype of the PAN.

\section{Peripheral neuroeffector function of primary afferent nociceptor peptides}

Peptides released from the peripheral terminals of PANs have potent biological activity. SP, the peptide studied most extensively in this regard, is released from the peripheral terminals of PANs when they are activated by noxious stimuli or by antidromic activation of the peripheral nerve (Bill et al., 1979; Brodin et al., 1981; Moskowitz et al., 1984; White and Helme, 1985). Direct application of SP to peripheral tissues produces vasodilatation and increases vascular permeability (Lembeck and Holzer, 1979; Saria, 1984), attracts white blood cells (Helme and Andrews, 1985; Saito et al., 1986), activates the phagocytic function of neutrophils (Payan et al., 1984) and macrophages (Bar-Shavit et al., 1980; Hartung et al., 1986), increases production and release of inflammatory mediators (e.g., lysosomal enzymes and eicosanoids) from these cells (Hartung et al., 1986), and degranulates mast cells resulting in local release of histamine (Johnson and Erdos, 1973). SP also stimulates relcase of prostaglandin $E_{2}$ and collagenase from cells in joints of patients with rheumatoid arthritis (Lotz et al., 1987), and induces the release of IL-1, tumor necrosis factor $\alpha$, and IL-6 from white blood cells (Lotz et al., 1988). This suggests a possible mechanism for the regulation of host defense responses by the nervous system.

That SP released by PANs actively contributes to joint inflammation is suggested by the observation that the destruction of PANs with capsaicin reduces the severity of experimental arthritis (Levine et al., 1986a). Furthermore, SP antagonists inhibit the neurogenic inflammation produced by PAN stimulation (Couture and Cuello, 1984), and the leakage of plasma induced by SP or by antidromic electrical stimulation of sensory nerves is completely inhibited by a selective antagonist of the $\mathrm{NK}_{1}$ receptor (Garret et al., 1991; Lembeck et al., 1992), one of three neurokinin receptors $\left(\mathrm{NK}_{1}, \mathrm{NK}_{2}\right.$, and $\left.\mathrm{NK}_{3}\right)$ that have been cloned and sequenced (Masu et al., 1987; Yokota et al., 1989; Shigemoto et al., 1990). These studies raised the possibility that neuropeptides released by primary afferents contribute to the inflammatory response in a variety of diseases, including arthritis (Levine et al., 1984b, 1985a), asthma (Barnes et al., 1991a,b), inflammatory bowel disease (Mantyh et al., 1988, 1989, 1991), and migraine headache (Moskowitz et al., 1984), and that neurokinin antagonists may be of clinical value for their amelioration.
Central terminals of primary afferent nociceptors: peptides as central neurotransmitters and neuromodulators

Neurokinins as primary afferent nociceptor neurotransmitters. PAN-derived SP is concentrated in laminae I and II [the substantia gelatinosa (SG)] of the spinal cord dorsal horn. These laminae contain nociresponsive neurons (Hökfelt et al., 1975) and, although iontophoresis of SP onto these neurons excites them (Henry, 1976), these results were not generally accepted as showing that SP is a "neurotransmitter" of PANs. To the contrary, the demonstration that dorsal horn nociresponsive neurons can be activated even when the SP content of the dorsal horn is reduced (e.g., after sciatic nerve section) led to the suggestion that peptides released by primary afferents serve a poorly defined "neuromodulatory," rather than neurotransmitter, function (Wall et al., 1981). Even the recent demonstration that SP-immunoreactive terminals of undoubted primary afferent origin (Carlton et al., 1989; see below) make synaptic contact with physiologically defined nociresponsive neurons did not reveal how SP contributes to the transmission of nociceptive input.

A variety of new approaches, including the development of better methods to monitor the release of peptides in the spinal cord, the design of more selective peptide antagonists, and the refinement of ultrastructural double labeling techniques (which allow several amino acids and peptides to be examined simultaneously in the same synaptic profile), have provided powerful evidence in favor of the hypothesis that SP is indeed a central ncurotransmitter of PANs. To implicate peptides in the transmission of nociceptive messages from PANs to second-order neurons requires the demonstration that they are released by pain-producing stimulation. In fact, the release of SP into the cerebrospinal fluid (CSF) of the cat can be evoked by peripheral nerve stimulation, but only at intensities that elicit pain-related responses, such as increased blood pressure and dilation of the pupils. Increased SP release is also produced by application of capsaicin to the skin, which preferentially activates PANs (Go and Yaksh, 1987).

Although CSF levels of SP are presumed to result from overflow secondary to release from the central terminals of PANs, recent evidence suggests an alternative source. Using antibodycoated glass microelectrodes, Duggan and Hendry (1986) evaluated the spatial distribution of released peptide in spinal cord. They found that electrical stimulation of cutaneous nerves at intensities high enough to activate PANs evokes the release of SP in the SG and at the surface of the spinal cord. They suggested that the peptide detected in the CSF derives from the peripheral terminals of branches of SP-containing primary afferents that innervate the pia mater of the spinal cord, rather than from central terminals of PANs that synapse upon spinal cord neurons.

The distance within the spinal cord over which neurokinins may act has also been studied by means of the antibody microprobe technique. Noxious stimuli evoke the release of SP and neurokinin A (NKA; a neurokinin that co-occurs with SP and that is presumably coreleased from primary afferent terminals; see below). However, NKA pcrsists in spinal tissue long after SP can no longer be detected (Duggan et al., 1990; Hope et al., 1990a,b). Furthermore, NKA can be detected at a considerable distance from its presumed sitc of relcase in the SG. Since SP, but not NKA, is rapidly degraded by neutral endopeptidase 24.11 (enkephalinase), it was proposed that the persistence and 
diffusion of NKA after release is due to its slower degradation. These results raise the possibility that some peptides released from PANs can exert effects at a considerable distance from their site of release, an observation consistent with the presence of mismatches between the distribution of peptides and their respective binding sites (Herkenham, 1987; Kruger et al., 1988a,b).

As described above, the effects of neurokinins result from an action on at least three different receptors, $\mathrm{NK}_{1}, \mathrm{NK}_{2}$, and $\mathrm{NK}_{3}$. The $\mathrm{NK}_{1}$ and $\mathrm{NK}_{2}$ receptors are thought to be targeted by $\mathrm{SP}$ and NKA, respectively. Consistent with their putative contribution to nociceptive processing, $\mathrm{NK}_{1}$ binding sites are densely concentrated in dorsal horn laminae I and II and along the medial half of the laminae III-X, as well as in the intermediolateral cell column. $\mathrm{NK}_{2}$ sites overlap considerably with the $\mathrm{NK}_{1}$ sites; $\mathrm{NK}_{3}$ sites are more restricted in their distribution, being densely concentrated in laminae I and II.

The antibody-coated glass microelectrode was also used to address the nature of the stimuli that evoke peptide release. Kuraishi et al. (1988) had reported that SP was released by noxious mechanical, but not thermal, stimulation. Duggan and colleagues confirmed that, at the temperature used by Kuraishi et al. $\left(<48.5^{\circ} \mathrm{C}\right)$, there is no SP release; however, noxious thermal stimuli did evoke the release of SP at temperatures above $52^{\circ} \mathrm{C}$ (Duggan et al., 1988). Although the release of SP at the higher temperature may simply reflect an increased number of impulses invading the central terminal of thermally sensitive nociceptors, it is possible that the higher temperatures induce tissue damage with associated inflammation and that chemicals released as a consequence may secondarily activate a separate population of chemosensitive, SP-containing PANs that are not directly sensitive to thermal stimuli. Consistent with the idea that inflammatory mediators in the periphery also act as stimuli for central release of SP, Schaible et al. (1990) reported that inflammation of the knee joint evokes the release of SP in the cat spinal cord.

Behavioral effects of substance $P$. In addition to the anatomical studies of SP distribution in the dorsal horn and the demonstration that it is released by noxious stimuli, the involvement of SP in the transmission of nociceptive messages by PANs is supported by the finding that nociceptive neurons of the dorsal horn are excited by local iontophoresis of SP (see below) and that lumbar intrathecal injection of SP, in both rats and mice, evokes a syndrome characterized by biting and scratching of the hindlimbs (Hylden and Wilcox, 1981; Piercey et al., 1981; Seybold et al., 1982). Based on the limited rostral spread of the peptide, Piercey et al. (1981) concluded that these behavioral effects indicate pain and result from a spinal action. These effects are mimicked by the $\mathrm{NK}_{1}$-selective agonist septide, but not by the $\mathrm{NK}_{3}$-selective agonist senktide (Papir-Kricheli et al., 1987).

Although some investigators have argued that these behaviors do not indicate pain (Bossut et al., 1988a,b; Frenk et al., 1988), other studies more directly link SP with pain behavior. For example, intraspinal injection of SP lowers the threshold for eliciting the thermal-evoked tail-flick reflex (Cridland and Henry, 1988c), and antagonists of SP block the facilitation of the tail-flick response produced by a concurrent noxious stimulus (Cridland and Henry, 1988b). The selective nonpeptide $\mathrm{NK}_{1}$ antagonist CP-96345 reduces the pain behavior produced by subcutaneous formalin (Yamamoto and Yaksh, 1991). Taken together, these results provide evidence that SP is a neurotransmitter of nociceptive PANs and that the intensity of the stim- ulus, its modality (Wiesenfeld-Hallin, 1986a,b; Ohno et al., 1988), and/or the degree to which the stimulus provokes inflammation are critical factors that determine the extent to which SP contributes to the transmission of nociceptive signals.

Substance $P$ actions on second-order neurons in spinal dorsal horn. Stimulation of dorsal roots in rat spinal cord in vitro produces an early, fast and a late, slow depolarization in dorsal horn neurons. The late, slow depolarization is blocked by an SP antagonist and cannot be demonstrated in spinal cords taken from rats in which C-fibers are destroyed by pretreatment with capsaicin (Urban and Randic, 1984). When SP is bath applied, dorsal horn neurons show a depolarization that is similar in time course to the late, slow depolarization evoked by dorsal root stimulation. Voltage-clamp studies show that this depolarization is due largely to the activation of a time- and voltagedependent inward $\mathrm{Ca}^{2+}$ current (Murase and Randic, 1984). The analysis of SP effects on ionic conductances is somewhat complicated, however, because SP also activates a $\mathrm{Ca}^{2+}$-activated voltage-sensitive $\mathrm{K}^{+}$current (which would oppose the SP-activated inward $\mathrm{Ca}^{2+}$ current) and a nonspecific cationic conductance that would act synergistically with the $\mathrm{Ca}^{2+}$ current $(\mathrm{Mu}-$ rase et al., 1989). In vivo electrophysiologicial studies have shown that locally iontophoresed SP can produce an excitatory effect that is slow in onset, of long duration, and selective for dorsal horn neurons that respond to noxious stimulation (Henry, 1976; Salter and Henry, 1991). A selective $\mathrm{NK}_{1}$ antagonist, CP 96345 , blocks responses of cat dorsal horn neurons to both noxious heat and iontophoretically applied SP (Radhakrishnan and Henry, 1991). Excitation of identified spinothalamic tract neurons by iontophoretically applied SP has also been demonstrated (Willcockson et al., 1984). Finally, using receptor-selective drugs, Fleetwood-Walker et al. (1990) found that both SP, acting via the $\mathrm{NK}_{1}$ receptor, and $\mathrm{NKA}$, acting via the $\mathrm{NK}_{2}$ receptor, excite nociceptive dorsal horn neurons.

Although SP has a predominantly excitatory effect at the synapse between PANs and dorsal horn nociceptive neurons, other in vivo experiments indicate that a subpopulation of dorsal horn neurons is inhibited by $\mathrm{SP}$, acting via the $\mathrm{NK}_{1}$ receptor (Fleetwood-Walker et al., 1990). In fact, bath-applied SP evokes a hyperpolarizing response in about one-third of dorsal horn neurons (Murase and Randic, 1984). This hyperpolarization is abolished by either TTX or high- $\mathrm{Mg}^{2+}$, low- $\mathrm{Ca}^{2+}$ solutions, suggesting that it is an indirect effect produced through an action of SP on an interneuron that synapses upon the recorded cell. A corollary of this observation is that some of the cells activated by SP inhibit other dorsal horn neurons. Since SP produces both direct excitation and indirect inhibition of dorsal horn nociceptive neurons, it is of interest that CNS injection of SP exerts both nociceptive and naloxone-reversible antinociceptive effects (Fredrickson et al., 1978). The antinociceptive effect may result from an SP-induced release of opioid peptides from dorsal horn interneurons. Indecd, such rclcase has been detected (Del Rio et al., 1983). More recently, however, Krumins et al. (1989) raised the possibility that the N-terminal fragment of SP might interact with opioid receptors and, in fact, demonstrated that SP1-9 and SP1-4, but not SP5-11 (i.e., the C-terminus of SP), reduce the affinity and increase the binding capacity of the $\mu$-opioid ligand DAMGO in mouse brain and spinal cord. They also provided evidence that the naloxone-antagonizable "behavioral desensitization" produced by repeated injections of SP is a consequence of the breakdown of SP into (1) a pronociceptive C-terminal fragment and (2) a desensitizing $\mathrm{N}$-terminal fragment that 
exerts its effects through the $\mu_{1}$ opioid binding site (Larson, 1988; Igwe et al., 1990a,b).

\section{Multiple primary afferent nociceptor neurotransmitters and their interactions}

Among the many peptides that are located in DRG neurons, CGRP provides one of the best examples of a neuromodulator, in the sense of a compound that exerts only limited effects by itself, and yet dramatically potentiates the effects of other compounds (particularly SP). Unlike SP (Helke et al., 1982), CGRPcontaining terminals in the dorsal horn appear to derive exclusively from DRG cells. Dorsal rhizotomy (Chung et al., 1988; Traub et al., 1989) virtually eliminates CGRP staining in the cord. Since neonatal capsaicin treatment destroys a large proportion of PANs, it is not surprising that it also significantly reduces the level of CGRP in the spinal cord (Franco-Cereceda et al., 1987; Hammond and Ruda, 1989). The CGRP-containing axons are largely unmyelinated or small-diameter myelinated and constitute almost $30 \%$ of the primary afferent axons of Lissauer's tract, the major afferent input to the superficial laminae of the dorsal horn (McNeill et al., 1988). Unlike SP, which is distributed extensively in both dorsal and ventral horn, CGRP terminals are concentrated in dorsal horn laminae I and II and in the reticulated region of lamina V (Carlton et al., 1988). Electron microscopic studies have established a direct connection between CGRP-containing primary afferents and secondorder nociceptive spinothalamic tract neurons (Carlton et al., 1990). Since SP and CGRP coexist in primary afferent dorsal horn terminals (Merighi et al., 1988; Fried et al., 1989; Plenderleith et al., 1990), the fact that CGRP at spinal levels is found only in primary afferents means that there are some direct SPcontaining PAN connections to dorsal horn neurons (Carlton et al., 1989).

In the primate many CGRP-immunoreactive terminals contact one another. This indicates that primary afferent terminals make axoaxonic contact with each other. This arrangement may provide the anatomical substrate for a regulation by CGRP of amino acid release from PANs. In fact, there is evidence that both SP and CGRP can regulate the release of amino acid neurotransmitters from primary afferent fibers (Kangrga and Randic, 1990; Smullin et al., 1990). Paradoxically, neither CGRP nor neurokinin binding sites have been demonstrated on primary afferent fibers [indeed, dorsal rhizotomy results in an increase in the numbers of such binding sites in the dorsal horn (Charlton and Helke, 1985)]. There is, in fact, an apparent mismatch in the distribution of CGRP-containing terminals and CGRP binding sites in the dorsal horn. Specifically, the binding sites are notably low in abundance in the SG (Kruger et al., 1988a).

Iontophoretically applied CGRP produces a slow-onset, longlasting excitation of nociceptive dorsal horn neurons in vivo (Miletic and Tan, 1988). In vilro studies have demonstrated that CGRP produces a slow depolarization by a direct action on nociceptive dorsal horn cells (Ryu et al., 1988). Importantly, Biella et al. (1991) demonstrated that concentrations of CGRP that alone have little or no consistent effect, markedly potentiate the excitatory effect of either SP or noxious stimulation on rat dorsal horn neurons in vivo. Furthermore, CGRP increases $\mathrm{Ca}^{2+}$ conductance in DRG cells (Ryu et al., 1988) and enhances the release of SP from spinal cord slices (Oku et al., 1987).

Consistent with CGRP contributing to nociceptive processing in the dorsal horn, Morton and Hutchison (1990), using the antibody microprobe technique, found that noxious thermal, mechanical, or electrical stimulation evokes the release of CGRP in the superficial dorsal horn. Furthermore, direct application to the spinal cord of antisera to CGRP has an antinociceptive action (Kuraishi et al., 1988), and CGRP enhances the effects produced by SP (Wiesenfeld-Hallin et al., 1984). For example, coadministration of SP and CGRP significantly increases the excitability of a nociceptive flexion reflex in the rat (Woolf and Wiesenfeld-Hallin, 1986). Although the mechanism through which the interaction between SP and CGRP is produced is not clear, there is evidence that CGRP may retard the enzymatic degradation of SP (Le Greves et al., 1985).

In addition to the interactions between peptides, there are also interactions between peptide and excitatory amino acid transmitters on dorsal horn neurons. Noxious stimulation evokes the release of glutamate and other amino acids that co-occur with the peptides in primary afferent terminals (Battaglia and Rustioni, 1988; De Biasi and Rustioni, 1988; Skilling et al., 1988; Smullin et al., 1990). In vivo, iontophoretically applied SP potentiates NMDA-induced responses in identified spinothalamic tract neurons (Dougherty and Willis, 1991). In wholecell voltage-clamp studies of dissociated dorsal horn neurons, SP markedly potentiates an inward glutamate-gated current (Randic et al., 1990). This modulatory effect of SP on the actions of excitatory amino acid transmitters contributes to the windup phenomenon, the property of nociceptive dorsal horn neurons whereby repeated activation of PANs results in a progressive increase in their discharge to each stimulus. This enhancement of discharge is blocked by either an SP (Kellstein et al., 1990) or an NMDA (Dickenson and Sullivan, 1990) antagonist.

In summary (Fig. 2), the available evidence is consistent with a model in which SP and CGRP produce slow-onset, longduration depolarizations that act synergistically to excite second-order nociceptive dorsal horn neurons, including identified spinothalamic tract neurons. In addition, there is a slow-onset, long-lasting potentiation of a glutamate-induced fast excitation. Since multiple neuromediators are released when PANs are active, a burst of activity in PANs should be sufficient to induce long-lasting activation of dorsal horn neurons.

\section{Other excitatory primary afferent nociceptor neuropeptides: cholecystokinin}

In some species cholecystokinin (CCK) is colocalized with SP and/or CGRP (Tuchscherer et al., 1987). Unfortunately, there is immunological cross-reactivity between CCK and CGRP, so the presence of CCK in primary afferents has been called into question (Duggan and Weihe, 1991). CCK immunoreactivity is also present in dorsal horn neurons and in the terminals of axons descending from supraspinal regions. Iontophoresis of CCK excites dorsal horn neurons in the rat (Jeftinija et al., 1981; Kellstein ct al., 1991); however, this effect is wcak, inconsistent, and neither dose related nor blocked by CCK antagonists. A more consistent and provocative effect is for CCK to antagonize and CCK antagonists to potentiate opioid suppression of $\mathrm{C}$-fiber activation of dorsal horn neurons (Kellstein et al., 1991). These electrophysiological data are consistent with behavioral studies (e.g., Watkins et al., 1984) and with some clinical reports of an analgesic effect of CCK antagonists (see Baber et al., 1989, for review). The antianalgesic action of CCK was recently put into a behavioral context by Wiertelak et al. (1992). Whereas fear and stress (e.g., produced by painful shocks) activate an endog- 
enous opioid-mediated analgesic effect, cues that signal safety from painful shocks reverse this antinociception as well as the antinociceptive effect of morphine. CCK antagonists block the reversal of both morphine and stress antinociception produced by such safety cues.

\section{Inhibitory neuropeptides in primary afferent nociceptors: somatostatin and galanin}

The classic view that primary afferents release only excitatory neurotransmitters is complicated not only by the finding that SP has both proalgesic and analgesic actions, but also by the evidence that SOM and galanin (GAL) (Randic et al., 1987) inhibit the firing of nociceptive-specific spinal cord neurons (Randic and Miletic, 1978; Miletic and Randic, 1982; Sandkuhler et al., 1990). In vitro studies indicate that the SOMinduced inhibition of dorsal horn cells is associated with a hyperpolarization of these neurons (Murase et al., 1982), which may be due to a G-protein-mediated reduction of $\mathrm{Ca}^{2+}$ conductance (Sah, 1990). Unfortunately, the lack of a specific antagonist makes it difficult to prove that the observed inhibition occurs under physiological conditions associated with SOM release.

GAL, which colocalizes with SP and CGRP in large numbers of primary afferent, capsaicin-sensitive C-fibers (Skofitsch and Jacobowitz, 1985; Klein et al., 1990), may also have an inhibitory effect on nociceptive transmission. In some studies of thermal nociception, intrathecal GAL is reported to have an antinociceptive effect (Cridland and Henry, 1988a; Post et al., 1988), although it lowered the threshold for vocalization in mcchanical tests at higher doses. Other studies reported that low doses of intrathecal GAL increase the excitability of the flexion reflex, while higher doses of GAL produce a prolonged depression of thermal nociceptive reflexes (Wiesenfeld-Hallin et al., 1988, $1989,1990)$. The higher doses also blocked the facilitatory effect of SP, CGRP, or conditioning stimulation of C-fibers (Xu et al., 1989, 1991). Thus GAL, like SP, appears to exert both pro- and antinociceptive effects.

\section{Modulation of primary afferent neurons at their central terminals}

Opioids applied directly to the spinal cord block behavioral responses to noxious stimulation in animals and produce profound antinociception in humans (see Yaksh et al., 1988, for review). Primary afferent terminals, local interneurons, and the dendrites of projection neurons whose somata lic in decper laminae are present in the SG and are potential targets of opioids. Opioids both reduce transmitter release from primary afferents and directly inhibit dorsal horn neurons. Although either of these actions could contribute to spinal mechanisms of antinociception, this article will focus on control of transmitter release from primary afferents.

The central terminals of small-diameter primary afferents contain $\mu, \delta$, and $\kappa$ opioid binding sites (LaMotte et al., 1976; Fields et al., 1980; Zajac et al., 1989; Gouardères et al., 1991). Studies of spinal cord slices clearly demonstrate that met-enkephalin, acting presynaptically, can inhibit glutaminergic input to neurons in lamina I (Hori et al., 1992). Electrophysiological studies of cultured DRG neurons provide evidence for a direct opioid action on primary afferents. Opioids shorten the plateau of the action potential, which is mainly due to a $\mathrm{Ca}^{2+}$ current (Mudge et al., 1979). In mouse DRG neurons, $\kappa$-opioid ligands block this voltage-dependent $\mathrm{Ca}^{2+}$ current. In contrast, $\mu$ - and

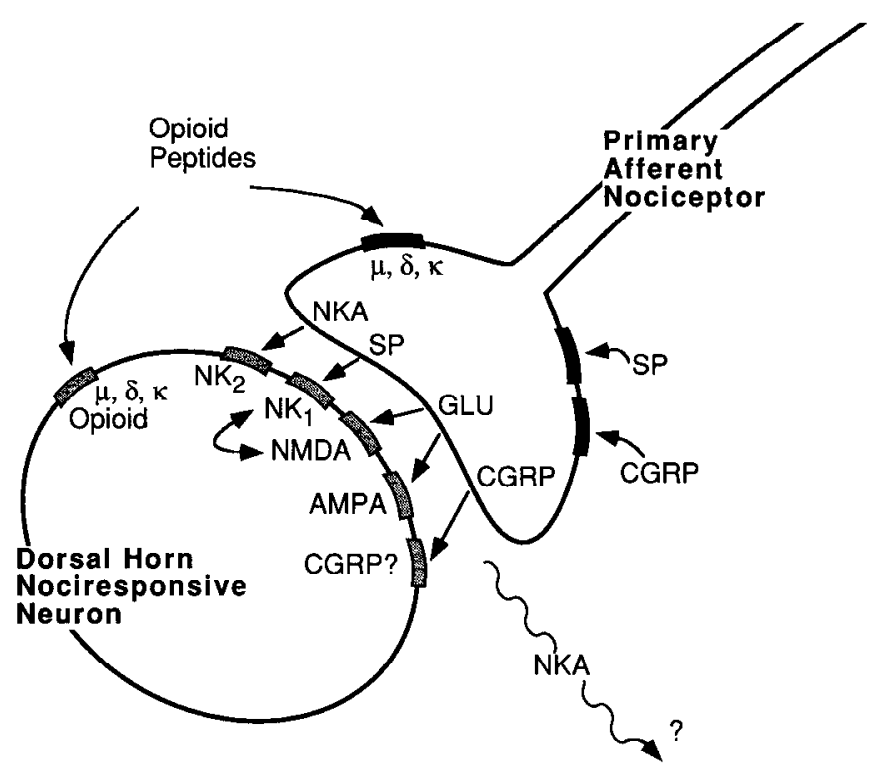

Figure 2. Primary afferents and peptide actions in the CNS. The PAN releases a variety of co-occurring neuropeptides $(N K A, S P, C G R P)$ and excitatory amino acids [e.g., glutamate $(G L U)]$. These act at several postsynaptic receptors: the $N K_{1}$ and $N K$, tachykinin receptors, the $C G R P$ receptor, and the $N M D A$ and $A M P A$ excitatory amino receptors. $N K A$ may diffuse to act at a distance from its site of release. There is evidence that $S P$ and $C G R P$ also act at autoreceptors at neuropeptide-containing primary afferent terminals. In addition, opioid peptides act upon both pre- and postsynaptic $\mu$-, $\delta$-, and $\kappa$-opioid receptors to modulate transmitter release and the firing of second-order nocircsponsivc ncurons.

$\delta$-ligands increase $\mathrm{K}^{+}$conductance, which secondarily shortens the $\mathrm{Ca}^{2+}$ current (Werz and MacDonald, 1983; MacDonald and Werz, 1986). If this reduction in inward $\mathrm{Ca}^{2+}$ current also occurs at the central terminals of adult DRG neurons, then transmitter release would be reduced. On the other hand, although Shen and Crain (1989) confirmed that micromolar concentrations of opioids shorten the action potential of cultured DRG neurons, they found that nanomolar concentrations of $\mu$, $\delta$, or $\kappa$ ligands prolong the action potential. Since this action potential is, in large part, due to an inward $\mathrm{Ca}^{2+}$ current, its prolongation should increase transmitter release. We should point out, however, that in these in vitro studies, the DRG populations did not respond uniformly to opioids and probably included several different physiological classes of primary afferent neurons.

It is generally accepted that opioids inhibit the release of SP from primary afferents in vitro (Jessell and Iversen, 1977; Mudge et al., 1979; Chang et al., 1989) and in vivo (Yaksh et al., 1980; Yonehara et al., 1986; Go and Yaksh, 1987; Aimone and Yaksh, 1989). Although $\mathrm{K}^{+}$-evoked SP release could derive from intrinsic dorsal horn neurons as well as primary afferents, the fact that the opioid-induced reduction of $\mathrm{K}^{+}$-evoked SP release is not observed in rats whose unmyelinated primary afferents are destroyed by neonatal treatment with capsaicin indicates that opioids do in fact inhibit SP release from PANs (Pohl et al., $1989 \mathrm{a})$. Furthermore, opioids also reduce $\mathrm{K}^{+}$- and capsaicinevoked release of CGRP, which at spinal levels is derived almost completely from primary afferents (Pohl et al., 1989b). On the other hand, recent experiments have raised questions about the interpretation of studies of the modulation of neuropeptide release that are based on sampling PAN neuropeptides in CSF. 
Specifically, using the antibody microprobe technique in cat dorsal horn, Morton et al. (1990) failed to demonstrate inhibition by morphine of the noxious stimulation-evoked release of either SP (Morton et al., 1990), NKA (Lang et al., 1991), or CGRP (Morton and Hutchison, 1990).

To some extent these discrepant results may be due to simultaneous action of opioids at different receptor sites. This issue has been addressed by the use of opioid receptor typeselective ligands. For example, in rat dorsal cord slices, selective $\delta$-ligands reduce capsaicin-evoked release of SP, but $\mu$-selective ligands significantly increase SP release (Pohl et al., 1989b). In these studies and in other in vivo work (Hirota et al., 1985), $\kappa$-ligands had no effect on SP release. Morcover, in slices of trigeminal dorsal horn, Suarez-Roca et al. (1992) found a complex dose-response curve for morphine: inhibition of $\mathrm{K}^{+}$-evoked SP release at low nanomolar and at low micromolar concentrations, and enhancement of release at high nanomolar and at high micromolar doses. Using receptor-selective antagonists, they showed that the low-nanomolar inhibition and the highnanomolar facilitation of SP release are $\mu$-effects; the low-micromolar inhibition is primarily $\delta$-mediated (see also Collin et al., 1991), and the high-nanomolar morphine facilitation is a k-effect (Suarez-Roca and Maixner, 1992; H. Suarez-Roca and W. Maixner, unpublished observations).

Finally, it is possible that the studies of the action of opioids at their peripheral terminals discussed above may be relevant to the actions of these drugs at the central terminals of PANs. Thus, opioids not only block transmitter release from the peripheral terminals of primary afferents (Yaksh, 1988), but also increase nociceptive threshold through inhibition of the CAMP second messenger in peripheral tissues (Levine and Taiwo, 1989; Taiwo and Levine, 1991a). To what extent a comparable action contributes at the central terminals of PANs must be examined.

In summary, each of the three major classes of opioid receptor may contribute to the opioid-induced modulation of transmission of nociceptive information in the dorsal horn. There is reasonably good evidence that both $\mu$ - and $\delta$-ligands act presynaptically to modulate peptide release from primary afferents, and postsynaptically to inhibit dorsal horn nociresponsive neurons directly, including identified projection cells. $\mu$-Ligands produce consistent and selective antinociceptive actions when applied to the SG, where the bulk of unmyelinated PANs terminate (Hope et al., 1990c). $\delta$-Ligands are active when applied to the surface of the cord and in lamina I, where myelinated PANs terminatc. The contribution of $k$-ligands is unresolved since both antinociceptive and pronociceptive actions have been seen when it is applied to the cord in different ways (FleetwoodWalker et al., 1988).

Although it is clear that opioids can modulate the release of neuropeptides from PANs, the contribution of this effect to the modulation of nociceptive transmission in the dorsal horn is uncertain. $\mu$ - and $\delta$-opioid agonists selectively inhibit the response of dorsal horn neurons to noxious stimulation when applied in the region of termination of PANs in superficial dorsal horn (Duggan and North, 1984; Fleetwood-Walker et al., 1988). While this effect could result from a reduction in transmitter release from PANs, postsynaptic actions on intrinsic dorsal horn neurons have also been demonstrated (Yoshimura and North, 1983; Jeftinija, 1988; Hope et al., 1990c).

If one accepts the likelihood that opioid modulation of the release of transmitter from the spinal terminals of PANs contributes to antinociception, it is natural to ask whether endog- enous opioid peptides could be involved in this control. In fact, there is a dense concentration of preproenkephalin-derived opioid peptides in terminals in the superficial dorsal horn. Although this distribution overlaps precisely the terminal fields of PANs, axoaxonic connections with enkephalin immunoreactivity onto PAN terminals have been looked for but not found (Glazer and Basbaum, 1984).

Support for the concept that enkephalins are indeed involved in the control of transmitter release from PANs derives from studies of enzymes that inactivate enkephalins. A prime candidate for inactivation of enkephalins is a neutral endopeptidase (NEP) that cleaves both met- and leu-enkephalin at the amide bond between glycine and phenylalanine. Immunocytochemical studies show a dense concentration of NEP immunoreactivity in the superficial dorsal horn, with its greatest density in the SG largely overlapping that of enkephalin and SP (Waksman et al., 1986; Back and Gorenstein, 1989; Pollard et al., 1989). Importantly, application of an NEP inhibitor to the spinal cord produces antinociception in animals (Oshita et al., 1990) and inhibits nociceptive dorsal horn neurons (Dickenson et al., 1987), although it is not clear that these effects are due to an action on PAN terminals.

\section{Summary}

An expanding knowledge of neuropeptides and their function has led to a profound change in our view of how the PAN contributes to pain. In addition to their expected direct action on postsynaptic cells in the dorsal horn, neuropeptides can modify transmitter release from nearby terminals of other PANs and/or diffuse to act on dorsal horn neurons at a considerable distance from their site of release (Fig. 2). Contrary to early expectations and despite the evidence that several neuropeptides excite central nociceptive neurons, there is no clear correspondence between neuropeptide content and physiologically defined classes of small-diameter primary afferents. There is, however, a tendency for populations of afferents innervating different organs to differ consistently in their peptide content. In fact, the peptide content of primary afferents is, in part, determined by specific factors in the tissues that they innervate. Furthermore, peptide content can change dramatically in response to certain prolonged stimuli or nerve damage. The lack of correspondence of peptide content and physiological response pattern, the plasticity of peptide content, its tissue specificity, and the possibility for action at a distance from the site of their release from central PAN terminals strongly suggest that PAN peptides have functions that are fundamentally different from those of the shortrange actions of amino acid neurotransmitters that are also found in the PAN. Finally, nowhere is the plasticity of function of the PAN more evident than at its peripheral terminals. Long-term changes are produced in these terminals by a host of peptides that derive from a variety of cell types. The complexity of this transduction process is augmented by the activity-induced release of peripherally active neuropeptides from the PAN itself.

In addition to the variety of fundamental neurobiological issues that recent studies of PANs have raised, they have also generated a great deal of clinical interest, in view of the role of the PAN in inflammation and its accessibility for study and for therapeutic intervention.

\section{References}

Abbott F (1988) Peripheral and central antinociceptive actions of ethylketocyclazocine in the formalin test. Eur J Pharmacol 152:93100. 
Aimone LD, Yaksh TL (1989) Opioid modulation of capsaicin-evoked release of substance $P$ from rat spinal cord in vivo. Peptides 10:11271131.

Baber NS, Dourish CT, Hill DR (1989) The role of CCK, caerulein, and CCK antagonists in nociception. Pain 39:307-328.

Back SA, Gorenstein C (1989) Fluorescent histochemical localization of neutral endopeptidase-24.11 (enkephalinase) in the rat spinal cord. J Comp Neurol 280:436-450.

Barbut D, Polak JM, Wall PD (1981) Substance P in spinal cord dorsal horn decreases following peripheral nerve injury. Brain Res 205:289298.

Barnes PJ, Baraniuk JN, Belvisi MG (1991a) Neuropeptides in the respiratory tract. Part I. Am Rev Respir Dis 144:1 187-1198.

Barnes PJ, Baraniuk JN, Belvisi MG (1991b) Neuropeptides in the respiratory tract. Part II. Am Rev Respir Dis 144:1391-1399.

Bar-Shavit Z, Goldman R, Stabinsky Y, Gottlieb P, Fridkin M, Teichberg VI, Blumberg S (1980) Enhancement of phagocytosis-a newly found activity of substance $P$ residing in its N-terminal tetrapeptide. Biochem Biophys Res Commun 94:1445-1451.

Basbaum AI, Levine JD (1991) Opiate analgesia: how central is a peripheral target? N Engl J Med 325:1168-1169.

Battaglia G, Rustioni A (1988) Coexistence of glutamate and substance $\mathrm{P}$ in dorsal root ganglion neurons of the rat and monkey. J Comp Neurol 277:302-312.

Berzetei IP, Yamamura HI, Duckles SP (1987) Characterization of rabbit ear artery opioid receptors using a delta-selective agonist and antagonist. Eur J Pharmacol 139:61-66.

Berzetei IP, Fong A, Yamamura HI, Duckles SP (1988) Characterization of kappa opioid receptors in the rabbit ear artery. Eur J Pharmacol 151:449-455.

Biella G, Panara C, Pecile A, Sotgiu ML (1991) Facilitatory role of calcitonin gene-related peptide (CGRP) on excitation induced by substance $\mathbf{P}(\mathrm{SP})$ and noxious stimuli in rat spinal dorsal horn neurons. An iontophoretic study in vivo. Brain Res 559:352-356.

Bill A, Stjernschatz J, Mandahl A, Brodin E, Nilsson G (1979) Substance $\mathbf{P}$ release on trigeminal nerve stimulation, effects in the eye. Acta Physiol Scand 106:371-373.

Bossut D, Frenk H, Mayer DJ (1988a) Is substance $P$ a primary afferent neurotransmitter for nociceptive input? II. Spinalization does not reduce and intrathecal morphine potentiates behavioral responses to substance $P$. Brain Res 455:232-239.

Bossut $D$, Frenk H, Mayer DJ (1988b) Is substance $P$ a primary afferent neurotransmitter for nociceptive input? IV. 2-Amino-5-phosphonovalerate (APV) and $\left[\mathrm{D}-\mathrm{Pro}^{2}, \mathrm{D}-\operatorname{Trp}^{7,9}\right]$-substance $\mathrm{P}$ exert different effects on behaviors induced by intrathecal substance $P$, strychnine and kainic acid. Brain Res 455:247-253.

Brodin E, Gazelius B, Olgart L, Nilsson G (1981) Tissue concentration and release of substance P-like immunoreactivity in the dental pulp. Acta Physiol Scand 111:141-149.

Burgess GM, Mullaney I, McNeill M, Dunn PM, Rang HP (1989) Second messengers involved in the mechanism of action of bradykinin in sensory neurons in culture. J Neurosci 9:3314-3325.

Burton LE, Wilson WH, Shooter EM (1978) Nerve growth factor in mouse saliva. Rapid isolation procedures for and characterization of 7S nerve growth factor. J Biol Chem 253:7807-7812.

Cameron AA, Leah JD, Snow PJ (1988) The coexistence of neuropeptides in feline sensory neurons. Neuroscience 27:969-979.

Carlton SM, McNeill DL, Chung K, Coggeshall RE (1988) Organization of calcitonin gene-related peptide-immunoreactive terminals in the primate dorsal horn. J Comp Neurol 276:527-536.

Carlton SM, LaMotte CC, Honda CN, Surmeier DJ, Delanerolle N, Willis WD (1989) Ultrastructural analysis of axosomatic contacts on functionally identified primate spinothalamic tract neurons. J Comp Neurol 281:555-566.

Carlton SM, Westlund KN, Zhang D, Sorkin LS, Willis WD (1990) Calcitonin gene-related peptide containing primary afferent fibers synapse on primate spinothalamic tract cells. Neurosci Lett 109:76-81.

Chang H, Berde CB, Holz GG, Steward GF, Kream RM (1989) Sufentanil, morphine, met-enkephalin, and kappa-agonist (U-50,488H) inhibit substance $P$ release from primary sensory neurons: a model for presynaptic spinal opioid actions. Anesthesiology 70:672-677.

Charlton CG, Helke CJ (1985) Autoradiographic localization and characterization of spinal cord substance $P$ binding sites: high densities in sensory, autonomic, phrenic, and Onuf's motor nuclei. J Neurosci 5:1653-1661.
Chung K, Lee WT, Carlton SM (1988) The effects of dorsal rhizotomy and spinal cord isolation on calcitonin gene-related peptide labelled terminals in the rat lumbar dorsal horn. Neurosci Lett 90:27-32.

Collin E, Mauborgne A, Bourgoin S, Chantrel D, Hamon M, Cesselin $F$ (1991) In vivo tonic inhibition of spinal substance $P$ (-like material) released by endogenous opioid(s) acting at $\mathrm{W}$ receptors. Neuroscience 44:725-731.

Couture R, Cuello AC (1984) Studies on the trigeminal antidromic vasodilatation and plasma extravasation in the rat. $\mathrm{J}$ Physiol (Lond) 346:273-285.

Cridland RA, Henry JL (1988a) Effects of intrathecal administration of neuropeptides on a spinal nociceptive reflex in the rat: VIP, galanin, CGRP, TRH, somatostatin and angiotensin II. Neuropeptides 11:2332.

Cridland RA, Henry JL (1988b) Facilitation of the tail-flick reflex by noxious cutaneous stimulation in the rat: antagonism by a substance $P$ analogue. Brain Res 462:15-21.

Cridland RA, Henry JL (1988c) N-and C-terminal fragments of substance P: spinal effects in the rat tail flick test. Brain Res Bull 20:429432.

Dayer JM, de Rochenonteix B, Burrus B, Demczuk S, Dinarello JM (1986) Human recombinant interleukin-1 stimulates collagenase and prostaglandin E-2 production by human synovial cells. J Clin Invest 77:645-648.

De Biasi S, Rustioni A (1988) Glutamate and substance $\mathbf{P}$ coexist in primary afferent terminals in the superficial laminae of spinal cord. Proc Natl Acad Sci USA 85:7820-7824.

Del Rio J, Naranjo JR, Yang H-YT, Costa E (1983) Substance P-induced release of met t $^{5}$ enkephalin from striatal and periaqueductal gray slices. Brain Res 279:121-126.

Dickenson AH, Sullivan AF (1990) Differential effects of excitatory amino acid antagonists on dorsal horn nociceptive neurones in the rat. Brain Res 506:31-39.

Dickenson AH, Sullivan AF, Fournie-Zaluski MC, Roques BP (1987) Prevention of degradation of endogenous enkephalins produces inhibition of nociceptive neurones in rat spinal cord. Brain Res 408: 185-191.

Dinarello CA (1989) Interleukin 1 and other growth factors. In: Textbook of rheumatology (Kelley WN, Harris ED Jr, Ruddy S, Sledge CB, eds), pp 285-299. New York: Saunders.

Dougherty PM, Willis WD (1991) Enhancement of spinothalamic neuron responses to chemical and mechanical stimuli following combined micro-iontophoretic application of $N$-methyl-D-aspartic acid and substance P. Pain 47:85-93.

Doughty SE, Atkinson ME, Shehab SA (1991) A quantitative study of neuropeptide immunoreactive cell bodies of primary afferent sensory neurons following rat sciatic nerve peripheral axotomy. Regul Pep 35:59-72.

Dray A, Perkins MN (1988) Bradykinin activates peripheral capsaicinsensitive fibres via a second messenger system. Agents Actions 25 : 214-215.

Dray A, Bettaney J, Forster P, Perkins MN (1988) Bradykinin-induced stimulation of afferent fibres is mediated through protein kinase $\mathrm{C}$. Neurosci Lett 91:301-307.

Duggan AW, Hendry IA (1986) Laminar localization of the sites of release of immunoreactive substance $P$ in the dorsal horn with antibody-coated microelectrodes. Neurosci Lett 68:134-140.

Duggan AW, North RA (1984) Electrophysiology of opioids. Pharmacol Rev 35:219-281.

Duggan AW, Weihe E (1991) Central transmission of impulses in nociceptors: events in the superficial dorsal horn. In: Towards a new pharmacotherapy of pain (Basbaum AI, Besson J-M, eds), pp 35-68. New York: Wiley.

Duggan AW, Hendry IA, Morton CR, Hutchison WD, Zhao ZQ (1988) Cutaneous stimuli releasing immunoreactive substance $P$ in the dorsal horn of the cat. Brain Res 451:261-273.

Duggan AW, Hope PJ, Jarrott B, Schaible HG (1990) Release, spread and persistence of immunoreactive neurokinin $A$ in the dorsal horn of the cat following noxious cutaneous stimulation. Studies with antibody microprobes. Neuroscience 35:195-202.

Dunn PM, Rang HP (1990) Bradykinin-induced depolarization of primary afferent nerve terminals in the neonatal rat spinal cord in vitro. Br J Pharmacol 100:656-660.

Ferreira SH, Nakamura M (1979) Prostaglandin hyperalgesia: the pe- 
ripheral analgesic activity of morphine, enkephalin and opioid antagonists. Prostaglandins 18:191-200.

Ferreira SH, Lorenzetti BB, Bristow AF, Poole S (1988) Interleukin-1 beta as a potent hyperalgesic agent antagonized by a tripeptide analogue. Nature 334:698-700.

Fields HL, Emson PC, Leigh BK, Gilbert RFT, Iversen LL (1980) Multiple opiate receptor sites on primary afferent fibers. Nature 284 : 351-353.

Fischer JE, Kopin IJ, Wurtman RJ (1964) Effects of lumbar sympathectomy on the uterine uptake of catecholamines. Nature 203:938939.

Fleetwood-Walker SM, Hope PJ, Mitchell R, El-Yassir N, Molony V (1988) The influence of opioid receptor subtypes on the processing of nociceptive inputs in the spinal dorsal horn of the cat. Brain Res 451:213-226.

Fleetwood-Walker SM, Mitchell R, Hope PJ, El-Yassir N, Molony V, Bladon CM (1990) The involvement of neurokinin receptor subtypes in somatosensory processing in the superficial dorsal horn of the cat. Brain Res 519:169-182.

Franco-Cereceda A, Henke H, Lunberg JM, Petermann JB, Hökfelt T, Fischer JA (1987) Calcitonin gene-related peptide (CGRP) in capsaicin-sensitive substance P-immunoreactive sensory neurons in animals and man: distribution and release by capsaicin. Peptides 8:399410

Fredrickson RCA, Burgis V, Harrell CE, Edwards TD (1978) Dual actions of substance $\mathrm{P}$ on nociception: possible role of endogenous opioids. Science 199:1359-1362.

Frenk H, Bossut D, Urca G, Mayer DJ (1988) Is substance P a primary afferent neurotransmitter for nociceptive input? I. Analysis of painrelated behaviors resulting from intrathecal administration of substance $P$ and 6 excitatory compounds. Brain Res 455:223-231.

Fried G, Franck J, Brodin E, Born W, Fischer JA, Hiort W, Hökfelt T (1989) Evidence for differential storage of calcitonin gene-related peptide, substance $P$ and serotonin in synaptosomal vesicles of rat spinal cord. Brain Res 499:315-324.

Garret C, Carruette A, Fardin V, Moussaoui S, Peyronel J-F, Blanchard J-C, Laduron PM (1991) Pharmacological properties of a potent and selective nonpeptide substance $P$ antagonist. Proc Natl Acad Sci USA 88:10208-10212.

Garrison JC (1990) Histamine, bradykinin, 5-hydroxytryptamine, and thcir antagonists. In: The pharmacological basis of therapeutics, 8th ed (Gilman AG, Rall TW, Nies AS, Taylor P, eds), pp 575-599. New York: Pergamon.

Garry MG, Miller KE, Seybold VS (1989) Lumbar dorsal root ganglia of the cat: a quantitative study of peptide immunoreactivity and cell size. J Comp Neurol 284:36-47.

Glazer EJ, Basbaum AI (1984) Axons which take up [3H] serotonin are presynaptic to enkephalin immunoreactive neurons in cat dorsal horn. Brain Res 298:386-391.

Go VLW, Yaksh TL (1987) Release of substance P from the cat spinal cord. J Physiol (Lond) 381:141-167.

Gonzales R, Goldyne ME, Taiwo YO, Levine JD (1989) Production of hyperalgesic prostaglandins by sympathetic postganglionic neurons. J Neurochem 53:1595-1598.

Gouardères C, Bcaudet A, Zajac J-M, Cros J, Quirion R (1991) High resolution radioautographic localization of [125I]FK-33-824-labelled $\mathrm{mu}$ opioid receptors in the spinal cord of normal and deafferented rats. Neuroscience 43:197-209.

Green T, Dockray GJ (1987) Calcitonin gene-related peptide and substance $P$ in afferents to the upper gastrointestinal tract in the rat. Neurosci Lett 76:151-156.

Green T, Dockray GJ (1988) Characterization of the peptidergic afferent innervation of the stomach in the rat, mouse and guinea pig. Neuroscience 25:181-193.

Haley JE, Dickenson AH, Schachter M (1989) Electrophysiological evidence for a role of bradykinin in chemical nociception in the rat. Neurosci Lett 97:198-202.

Hammond DL, Ruda MA (1989) Developmental alterations in thermal nociccptive threshold and the distribution of immunoreactive calcitonin gene-related peptide and substance P after neonatal administration of capsaicin in the rat. Neurosci Lett 97:57-62.

Hammond DL, Ruda MA (1991) Developmental alterations in nociceptive threshold, immunoreactive calcitonin gene-related peptide and substance $P$, and fluoride-resistant acid phosphatase in neonatally capsaicin-treated rats. J Comp Neurol 312:436-450.
Hargreaves K, Joris J, Dubner R (1987) Peripheral actions of opiates in the blockade of carrageenan-induced cutaneous hyperalgesia. Pain [Suppl] 4:s17.

Hartung H-P, Wolters K, Tokya KV (1986) Substance P binding properties and studies on cellular responses in guinea-pig macrophages. $J$ Immunol 136:3856-3863.

Helke CJ, Neil JJ, Massari VJ, Loewy AD (1982) Substance P neurons project from the ventral medulla to the intermediolateral cell column and ventral horn in the rat. Brain Res 243:147-152.

Helme RD, Andrews PV (1985) The effect of nerve lesions on the inflammatory response to injury. J Neurosci Res 13:453-459.

Helme RD, Koschorke GM, Zimmerman M (1986) Immunoreactive substance $P$ release from skin nerves in rat by noxious thermal stimulation. Neurosci Lett 63:295-299.

Henry JL (1976) Effects of substance P on functionally identified units in cat spinal cord. Brain Res 114:439-451.

Herkenham M (1987) Mismatches between neurotransmitter and receptor localizations in brain: observations and implications. Neuroscience 23:1-38.

Heumann R, Korsching S, Bandtlow C, Thoenen H (1987a) Changes of nerve growth factor synthesis in nonneuronal cells in response to sciatic nerve transection. J Cell Biol 104:1623-1631.

Heumann R, Lindholm D, Bandtlow C, Meyer M, Radeke MJ, Misko TP, Schooter E, Thoenen H (1987b) Differential regulation of mRNA encoding nerve growth factor and its receptor in sciatic nerve during development, degeneration, and regeneration: role of macrophages. Proc Natl Acad Sci USA 84:8735-8739.

Hirota N, Kuraishi Y, Hino Y, Sato Y, Satoh M, Takagi H (1985) Met-enkephalin and morphine but not dynorphin inhibit noxious stimuli-induced release of substance $P$ from rabbit dorsal horn in situ. Neuropharmacology 24:567-570.

Hökfelt T, Kellerth J-O, Nilsson G, Pernow B (1975) Substance P: localization in the central nervous system and in some primary sensory neurons. Science 190:889-890.

Hökfelt T, Wiesenfeld-Hallin Z, Villar MJ, Melander T (1987) Increase of galanin-like immunoreactivity in rat dorsal root ganglion cells after peripheral axotomy. Neurosci Lett 83:217-220.

Hope PI, Fleetwood-Walker SM, Mitchell R (1990a) Distinct antinociceptive actions mediated by different opioid receptors in the region of lamina I and laminae III-V of the dorsal horn of the rat. $\mathrm{Br} \mathrm{J}$ Pharmacol 101:477-483.

Hope PJ, Lang CW, Duggan AW (1990b) Persistence of immunoreactive neurokinins in the dorsal horn of barbiturate anaesthetized and spinal cats, following release by tibial nerve stimulation. Neurosci Lett 118:25-28.

Hope PJ, Jarrott B, Schaible HG, Clarke RW, Duggan AW (1990c) Release and spread of immunoreactive neurokinin $A$ in the cat spinal cord in a model of acute arthritis. Brain Res 533:292-299.

Horgan K, Van der Kooy D (1992) Visceral targets specify calcitonin gene-related peptide and substance $P$ enrichment in trigeminal afferent projections. J Neurosci 12:1135-1143.

Hori Y, Endo K, Takahashi T (1992) Presynaptic inhibitory action of enkephalin on excitatory transmission in superficial dorsal horn of rat spinal cord. J Physiol (Lond) 450:s673-s685.

Hughes J (1981) Peripheral opiate receptor mechanisms. Trends Pharmacol Sci 2:21-24.

Hylden JLK, Wilcox GL (1981) Intrathecal substance P elicits a caudally-directed biting and scratching behavior. Brain Res 217:212215 .

Igwe OJ, Sun X, Larson AA (1990a) Correlation of substance Pinduced desensitization with substance $P$ amino terminal metabolites in the mouse spinal cord. Peptides 11:817-825.

Igwe. OJ, Sun X, Larson AA (1990b) Role of substance P amino terminal metabolites in substance $\mathrm{P}$-induced desensitization in mice. Neuroscience 36:535-542.

Illes P, 7ieglgansherger W, Herz A (1980a) Calcium reverses the inhibitory action of morphine on neuroeffector transmission in the mouse vas deferens. Brain Res 191:511-522.

Illes $P$, Zieglgansberger W, Herz $\Lambda$ (1980b) Lack of cross-tolerance between morphine and leu-enkephalin in the mouse vas deferens. Brain Res 197:260-263.

Illes P, Pfeiffer N, von Kugelgen I, Starke K (1985) Presynaptic opioid receptor subtypes in the rabbit ear artery. J Pharmacol Exp Ther 232: 526-533.

Jeftinija S (1988) Enkephalins modulate excitatory synaptic trans- 
mission in the superficial dorsal horn by acting at $\mu$-opioid receptor sites. Brain Res 460:260-268.

Jeftinija S, Miletic V, Randic M (1981) Cholecystokinin octapeptide excites dorsal horn neurons both in vivo and in vitro. Brain Res 213: 231-236.

Jessell TM, Iversen LL (1977) Opiate analgesics inhibit substance P release from rat trigeminal nucleus. Nature 268:549-551.

Johnson AR, Erdos EG (1973) Release of histamine from mast cells by vasoactive peptides. Proc Soc Exp Biol Med 142:1252-1256.

Jonsson C-E, Brodin E, Dalsgaard C-J, Haegerstrand A (1986) Release of substance P-like immunoreactivity in dog paw lymph after scalding injury. Acta Physiol Scand 126:21-24.

Joris JL, Dubner R, Hargreaves KM (1987) Opioid analgesia at peripheral sites: a target for opioids released during stress and inflammation. Anesth Analg (Cleve) 66:1277-1281.

Kangrga I, Randic M (1990) Tachykinins and calcitonin gene-related peptide enhance release of endogenous glutamate and aspartate from the rat spinal dorsal horn slice. J Neurosci 10:2026-2038.

Kavelaars A, Ballieux RE, Heijnen CJ (1989) The role of IL-1 in the corticotropin-releasing factor and arginine-vasopressin-induced secretion of immunoreactive beta-endorphin by human peripheral blood mononuclear cells. J Immunol 142:2338-2342.

Kellstein DE, Price DD, Hayes RL, Mayer DJ (1990) Evidence that substance $P$ selectively modulates $C$-fiber-evoked discharges of dorsal horn nociceptive neurons. Brain Res 526:291-298.

Kellstein DE, Price DD, Mayer DJ (1991) Cholecystokinin and its antagonist lorglumide respectively attenuate and facilitate morphineinduced inhibition of C-fiber evoked discharges of dorsal horn nociceptive neurons. Brain Res 540:302-306.

King JS, Galiant P, Myerson V, Perl ER (1976) The effects of inflammatory agents on the responses and the sensitization of unmyelinated (C) fiber polymodal nociceptors. In: Werner-Gren Center international symposium series, Vol 27 , Sensory functions of the skin in primate, with special reference to man (Zotterman Y, ed), pp 441461. Oxford: Pergamon.

Kirchhoff C, Jung S, Reeh PW, Handwerker HO (1990) Carrageenan inflammation increases bradykinin sensitivity of rat cutaneous nociceptors. Neurosci Lett 111:206-210.

Klein CM, Westlund KN, Coggeshall RE (1990) Percentages of dorsal root axons immunoreactive for galanin are higher than those immunorcactive for calcitonin gene-related peptide in the rat. Brain Res 519:97-101.

Koltzenberg M, Kress M, Reeh PW (1991) The nociceptor sensitization by bradykinin does not depend on sympathetic neurons. Neuroscience 46:465-473.

Kruger L, Mantyh PW, Sternini C, Brecha NC, Mantyh CR (1988a) Calcitonin gene-related peptide (CGRP) in the rat central nervous system: patterns of immunoreactivity and receptor binding sites. Brain Res 463:223-244.

Kruger L, Sternini C, Brecha NC, Mantyh PW (1988b) Distribution of calcitonin gene-related peptide immunoreactivity in relation to the rat central somatosensory projection. J Comp Neurol 273:149-162.

Krumins SA, Kim DC, Seybold VS, Larson AA (1989) Modulation of [3H]DAGO binding by substance P (SP) and SP fragments in the mouse brain and spinal cord via $\mathrm{mu}_{1}$ interactions. Neuropeptides 13:225-233.

Kumazawa T, Mizumura K, Minigawa M, Tsujii Y (1991) Sensitizing effects of bradykinin on the heat responses of the visceral nociceptor. J Neurophysiol 66:1819-1824.

Kuraishi Y, Nanayama T, Ohno H, Minami M, Satoh MM (1988) Antinociception induced in rats by intrathecal administration of antiserum against calcitonin gene-related peptide. Neurosci Lett 92:325329.

Laduron PM (1984) Axonal transport of opiate receptors in capsaicinsensitive neurones. Brain Res 294:157-160.

LaMotte CC, Pert CB, Snyder SH (1976) Opiate receptor binding in primate spinal cord: distribution and changes after dorsal root section. Brain Res 112:407-412.

LaMotte RH, Thalhammer JG, Torebjork HE, Robinson CJ (1982) Peripheral neural mechanisms of cutaneous hyperalgesia following mild injury to heat. J Neurosci $2: 765-781$.

LaMotte RH, Thalhammer JG, Robinson CJ (1983) Peripheral neural correlates of magnitude of cutaneous pain and hyperalgesia: a comparison of neural events in monkey with sensory judgements in humans. J Neurophysiol 50:1-26.
Lang CW, Duggan AW, Hope PJ (1991) Analgesic doses of morphine do not reduce noxious stimulus-evoked release of immunoreactive neurokinins in the dorsal horn of the spinal cat. $\mathrm{Br} \mathrm{J}$ Pharmacol 103: 1871-1876.

Lang E, Novak A, Reeh PW, Handwerker HO (1990) Chemosensitivity of fine afferents from rat skin in vitro. J Neurophysiol 63:887901.

Larson AA (1988) Desensitization to intrathecal substance $P$ in mice: possible involvement of opioids. Pain 32:367-374.

I eah JD, Cameron AA, Snow PJ (1985) Neuropeptides in physiologically identified mammalian sensory neurones. Neurosci Lett 56:257263.

Le Greves P, Nyberg F, Terenius L, Hökfelt T (1985) Calcitonin-gene related peptide is a potent inhibitor of substance $\mathrm{P}$ degradation. Eur J Pharmacol 115:309-311.

Lembeck F, Holzer P (1979) Substance $P$ as neurogenic mediator of antidromic vasodilation and neurogenic plasma extravasation. Naunyn Schmiedebergs Arch Pharmacol 310:175-183.

Lembeck F, Popper H, Juan H (1976) Release of prostaglandins by bradykinin as an intrinsic mechanism of its algesic effect. Naunyn Schmiedebergs Arch Pharmacol 294:69-73.

Lembeck F, Donnerer J, Tsuchiya M, Nagahisa A (1992) The nonpeptide tachykinin antagonist, CP-96,345, is a potent inhibitor of neurogenic inflammation. $\mathrm{Br} \mathrm{J}$ Pharmacol 105:527-530.

Levine JD, Taiwo YO (1989) Involvement of the mu-opiate receptor in peripheral analgesia. Neuroscience 32:571-575.

Levine JD, Lau W, Kwiat G, Goetzl EJ (1984a) Leukotriene $B_{4}$ produces hyperalgesia that is dependent on polymorphonuclear leukocytes. Science 225:743-745.

Levine JD, Clark R, Devor M, Moskowitz MA, Basbaum AI (1984b) Intraneuronal substance $P$ contributes to the severity of experimental arthritis. Science 226:547-549.

Levine JD, Collier DH, Basbaum AI, Helms C, Moskowitz MA (1985a) The nervous system may contribute to the pathogenesis of rheumatoid arthritis. J Rheumatol 12:406-411

Levine JD, Gooding J, Donatoni P, Borden L, Goetzl EJ (1985b) The role of the polymorphonuclear leukocyte in hyperalgesia. J Neurosci 5:3025-3029.

Levine JD, Dardick SJ, Roizen MF, Helms C, Basbaum AI (1986a) The contribution of sensory afferents and sympathetic efferents to joint injury in experimental arthritis. J Neurosci 6:3923-3929.

Levine JD, Lam D, Taiwo YO, Donatoni P, Goetzl EJ (1986b) Hyperalgesic properties of 15-lipoxygenase products of arachidonic acid. Proc Natl Acad Sci USA 83:5331-5334.

Levine JD, Taiwo Y, Collins S, Tam J (1986c) Noradrenaline hyperalgesia is mediated through interaction with sympathetic postganglionic neurone terminals rather than activation of primary afferent nociceptors. Nature 323:158-159.

Lewis RA (1989) Prostaglandins and leukotrienes. In: Textbook of rheumatology, 3d ed (Kelley WN, Harris ED Jr, Ruddy S, Sledge CB, eds), pp 258-260. Philadelphia: Saunders.

Lewis RA, Soter NA, Corey EJ, Austen KF (1984) Local effects of synthetic leukotrienes (LTs) on monkey (M) and human (H) skin. Clin Res 29:492A.

Lindholm D, Heumann R, Meyer M, Thoenen H (1987) Interleukin-1 regulates synthesis of nerve growth factor in non-neuronal cells in rat sciatic nerve. Nature 330:658-659.

Lotz M, Carson D, Vaughan JH (1987) Substance P activation of rheumatoid synoviocytes: neural pathway in pathogenesis of arthritis. Science 235:893-895

Lotz M, Vaughan JH, Carson DA (1988) Effect of neuropeptides on production of inflammatory cytokines by human monocytes. Science 241:1218-1221.

Lynn B (1990) Capsaicin: action on nociceptive C-fibres and therapeutic potential. Pain 41:61-69.

MacDonald RL, Werz MA (1986) Dynorphin A decreases voltagedependent calcium conductance of mouse dorsal root ganglion neurones. J Physiol (Lond) 377:237-249.

Madison S, Whitsel EA, Suarez-Roca H, Maixner W (1992) Sensitizing effects of leukotriene $B_{4}$ on intradental primary afferents. Pain 49:99104.

Mantyh PW, Mantyh CR, Gates T, Vigna SR, Maggio JE (1988) Receptor binding sites for substance $P$ and substance $K$ in the canine gastrointestinal tract and their possible role in inflammatory bowel disease. Neuroscience 25:817-837. 
Mantyh PW, Catton MD, Boehmer CG, Welton ML, Passaro EP Jr, Maggio JE, Vigna SR (1989) Receptors for sensory neuropeptides in human inflammatory diseases: implications for the effector role of sensory neurons. Peptides 10:627-645.

Mantyh PW, Catton MD, Maggio JE, Vigna SR (1991) Alterations in receptors for sensory neuropeptides in human inflammatory bowel disease. Adv Exp Med Biol 298:253-283.

Martin HA, Basbaum AI, Goetzl EJ, Levine JD (1988) Leukotriene $\mathrm{B}_{4}$ decreases the mechanical and thermal thresholds of $\mathrm{C}$-fiber nociceptors in the hairy skin of the rat. $J$ Neurophysiol 60:438-445.

Masu Y, Nakayama K, Tamaki H, Harada Y, Kuno M, Nakanishi S (1987) cDNA cloning of bovine substance-K receptor through oocyte expression system. Nature 329:836-838.

McMahon SB, Gibson S (1987) Peptide expression is altered when afferent nerves reinnervate inappropriate tissue. Neurosci Lett 73:915.

McNeill DL, Coggeshall RE, Carlton SM (1988) A light and electron microscopic study of calcitonin gene-related peptide in the spinal cord of the rat. Exp Neurol 99:699-708

Merighi A, Polak JM, Gibson SJ, Gulbenkian S, Valentino KL, Peirone SM (1988) Ultrastructural studies on calcitonin gene-related peptide-, tachykinins- and somatostatin-immunoreactive neurones in rat dorsal root ganglia: evidence for the colocalization of different peptides in single secretory granules. Cell Tissue Res 254:101-109.

Meyer RA, Campbell JN (1981) Myelinated nociceptive afferents account for the hyperalgesia that follows a burn to the hand. Science 213:1527-1529.

Miletic V, Randic M (1982) Neonatal rat spinal cord slice preparation: postsynaptic effects of neuropeptides on dorsal horn neurons. Dev Brain Res 2:432-438.

Miletic V, Tan H (1988) Iontophoretic application of calcitonin generelated peptide produces a slow and prolonged excitation of neurons in the cat lumbar dorsal horn. Brain Res 446:169-172.

Molander C, Ygge J, Dalsgaard C-J (1987) Substance P-, somatostatinand calcitonin gene-related peptide-like immunoreactivity and fluoride-resistant acid phosphatase-activity in relation to retrogradely labeled cutaneous, muscular and visceral primary sensory neurons in the rat. Neurosci Lett 74:37-42.

Morton CR, Hutchison WD (1990) Morphine does not reduce the intraspinal release of calcitonin gene-related peptide in the cat. Neurosci Lett 117:319-324.

Morton CR, Hutchison WD, Duggan AW, Hendry IA (1990) Morphine and substance $P$ release in the spinal cord. Exp Brain Res 82: 89-96.

Moskowitz MA, Brody M, Liu-Chen L-Y (1984) In vitro release of immunoreactive substance $P$ from putative afferent nerve endings in bovine pia arachnoid. Neuroscience 9:809-814.

Mudge AW, Leeman SE, Fischbach GD (1979) Enkephalin inhibits the release of substance $P$ from sensory neurons in culture and decreases action potential duration. Proc Natl Acad Sci USA 76:54875491.

Murasc K, Randic M (1984) Actions of substance $\mathbf{P}$ on rat spinal dorsal horn neurones. J Physiol (Lond) 346:203-217.

Murase K, Nedelikov V, Randic M (1982) The actions of neuropeptides on dorsal horn neurons in the rat spinal cord slice preparation: an intracellular study. Brain Res 234:170-176.

Murase K, Ryu PD, Randic M (1989) Tachykinins modulate multiple ionic conductances in voltage-clamped rat spinal dorsal horn neurons. J Neurophysiol 61:854-865.

Nicol GD, Klingberg DK, Vasko MR (1992) Prostaglandin E, increases calcium conductance and stimulates release of substance $P$ in avian sensory neurons. J Neurosci 12:1917-1927.

Noguchi K, Morita Y, Kiyama H, Ono K, Tohyama M (1988) A noxious stimulus induces the preprotachykinin-A gene expression in the rat dorsal root ganglion: a quantitative study using in situ hybridization histochemistry. Mol Brain Res 4:31-35.

Noguchi K, Senba E, Morita Y, Sato M, Tohyama M (1989) PreproVIP and preprotachykinin mRNAs in the rat dorsal root ganglion cells following peripheral axotomy. Mol Brain Res 6:327-330.

Noguchi K, Senba E, Morita Y, Sato M, Tohyama M (1990) AlphaCGRP and beta-CGRP mRNAs are differentially regulated in the rat spinal cord and dorsal root ganglion. Brain Res 7:299-304.

O'Brien C, Woolf CJ, Fitzgerald M, Lindsay RM, Molander C (1989) Differences in the chemical expression of the rat primary afferent neurons which innervate skin, muscle or joint. Neuroscience 32:493502.
Ohno H, Kuraishi Y, Minami M, Satoh M (1988) Modality-specific antinociception produced by intrathecal injection of anti-somatostatin antiserum in rats. Brain Res 474:197-200.

Oku R, Satoh M, Fujii N, Otaka A, Yajima H, Takagi H (1987) Calcitonin gene-related peptide promotes mechanical nociception by potentiating release of substance $P$ from the spinal dorsal horn in rats. Brain Res 403:350-354.

Oshita S, Yaksh TL, Chipkin R (1990) The antinociceptive effects of intrathecally administered SCH 32615 , an enkephalinase inhibitor in the rat. Brain Res 515:143-148.

Ositelu DO, Morris R, Vaillant V (1987) Innervation of facial skin but not masticatory muscles or the tongue by trigeminal primary afferents containing somatostatin in the rat. Neurosci Lett 78:271276.

Papir-Kricheli D, Frey J, Laufer R, Gilon C, Chorev M, Selinger Z, Devor M (1987) Behavioural effects of receptor-specific substance $P$ agonists. Pain 31:263-276.

Payan DG, Levine JD, Goetzl EJ (1984) Modulation of immunity and hypersensitivity by sensory neuropeptides. J Immunol 132:16011604.

Piercey MF, Dobry PJK, Schroeder LA, Einspahr FJ (1981) Behavioral evidence that substance $P$ may be a spinal cord sensory neurotransmitter. Brain Res 210:407-412.

Pitchford S, Levine JD (1991) Prostaglandins sensitize nociceptors in cell culture. Neurosci Lett 132:105-108.

Plenderleith MB, Haller CJ, Snow PJ (1990) Peptide coexistence in axon terminals within the superficial dorsal horn of the rat spinal cord. Synapse 6:344-350.

Pohl M, Mauborgne A, Bourgoin S, Benoliel JJ, Hamon M, Cesselin F (1989a) Neonatal capsaicin treatment abolishes the modulations by opioids of substance $\mathbf{P}$ release from rat spinal cord slices. Neurosci Lett 96:102-107.

Pohl M, Lombard MC, Bourgoin S, Carayon JA, Benoliel JJ, Mauborgne A, Besson JM, Hamon M, Cesselin F (1989b) Opioid control of the in vitro release of calcitonin gene-related peptide from primary afferent fibres projecting in the rat cervical cord. Neuropeptides 14:151-159.

Pollard H, Bouthenet M, Moreau J, Souil E, Verroust P, Ronco P, Schwartz JC (1989) Detailed immunoautoradiographic mapping of enkephalinase (EC 3.4.24.11) in rat central nervous system: comparison with enkephalins and substance $P$. Neuroscience 30:339-376.

Post C, Alari L, Hökfelt T (1988) Intrathecal galanin increases the latency in the tail flick and hot plate tests in mouse. Acta Physiol Scand 132:583-584.

Rackham A, Ford-Hutchinson AW (1983) Inflammation and pain sensitivity: effects of leukotrienes $D_{4}, B_{4}$ and prostaglandin $E_{1}$, in the rat paw. Prostaglandins 25:193-203.

Radhakrishnan V, Henry JL (1991) Novel substance P antagonist, CP-96,345, blocks responses of cat spinal dorsal horn neurons to noxious cutaneous stimulation and to substance P. Neurosci Lett 132: $39-43$.

Raja SN, Kozak SL, Manning DC, Meyer RA, Campbell JN (1990) Intradermal bradykinin induces hyperalgesia to heat stimuli in man. Pain [Suppl] 5:S130.

Randic M, Miletic V (1978) Depressant actions of methionine-enkephalin and somatostatin in cat dorsal hom neurones activated by noxious stimuli. Brain Res 152:196-202.

Randic M, Gernver G, Ryu PD, Kangrga I (1987) Inhibitory actions of galanin and somatostatin 28 on rat spinal dorsal horn neurons. Soc Neurosci Abstr 13:1308.

Randic M, Hecimovic H, Ryu PD (1990) Substance P modulates glutamate-induced currents in acutely isolated rat spinal dorsal horn neurones. Neurosci Lett 117:74-80.

Rosen H, Behar O, Abramsky O, Ovadia H (1989) Regulated expression of proenkephalin A in normal lymphocytes. J Immunol 143 3703-3707.

Russell NJW, Schaible H-G, Schmidt RF (1987) Opiates inhibit the discharges of fine afferent units from inflamed knee joint of the cat. Neurosci Lett 76:107-112.

Ryu PD, Gerber G, Murase K, Randic M (1988) Actions of calcitonin gene-related peptide on rat spinal dorsal horn neurons. Brain Res 441: 357-361.

Sah DW (1990) Neurotransmitter modulation of calcium current in rat spinal cord neurons. J Neurosci 10:136-141.

Saito A, Kimura S, Goto K (1986) Calcitonin gene-related peptide as potential neurotransmitter in guinea-pig right atrium. Am J Physiol 250:H693-H698. 
Salter MW, Henry JL (1991) Responses of functionally identified neurones in the dorsal horn of the cat spinal cord to substance $P$, neurokinin A and physalaemin. Neuroscience 43:601-610.

Sandkuhler J, Fu QG, Helmchen C (1990) Spinal somatostatin superfusion in vivo affects activity of cat nociceptive dorsal horn neurons: comparison with spinal morphine. Neuroscience 32:565-576.

Saria A (1984) Substance $P$ in sensory nerve fibers contributes to the development of oedema in the rat hindpaw after thermal injury. $\mathrm{Br}$ J Pharmacol 323:341-342.

Saria A, Martling C-R, Yan Z, Theodorsson-Norheim E, Gamse R, Lundberg JM (1988) Release of multiple tachykinins from capsaicin-sensitive sensory nerves in the lung by bradykinin, histamine, dimethylphenylpipcrazinium and vagal stimulation. Am Rev Respir Dis 137:1330-1335.

Schaible HG, Jarrott B, Hope PJ, Duggan AW (1990) Release of immunoreactive substance $P$ in the spinal cord during development of acute arthritis in the knee joint of the cat: a study with antibody microprobes. Brain Res 529:214-223.

Seybold VS, Hylden JLK, Wilcox GL (1982) Intrathecal substance P and somatostatin in rats: behaviors indicative of sensation. Peptides 3:49-54.

Shen K-F, Crain SM (1989) Dual opioid modulation of the action potential duration of mouse dorsal root ganglion neurones in culture. Brain Res 491:227-242.

Shigemoto R, Yokota Y, Tsuchida K, Nakanishi S (1990) Cloning and expression of a rat neuromedin $\mathrm{K}$ receptor cDNA. J Biol Chem 265:623-628.

Skilling SR, Smullin DH, Beitz AJ, Larson AA (1988) Extracellular amino acid concentrations in the dorsal spinal cord of freely moving rats following veratridine and nociceptive stimulation. $J$ Neurochem 51:127-132.

Skofitsch G, Jacobowitz DM (1985) Galanin-like immunoreactivity in capsaicin sensitive sensory neurons and ganglia. Brain Res Bull 15: 191-195.

Smith EM, Morril AC, Meyer WJ, Blalock JE (1986) Corticotropin releasing factor induction of leukocyte-derived immunoreactive ACTH and endorphins. Nature 321:881-882.

Smith GD, Harmar AJ, McQueen DS, Seckl JR (1992) Increase in substance $P, C G R P$, but not somatostatin content of innervating dorsal root ganglia in adjuvant monoarthritis in the rat. Neurosci Lett $137: 257-260$

Smith TW, Buchan P, Parsons DN, Wilkinson S (1988) Peripheral antinociceptive effects of $N$-methyl morphine. Life Sci 31:1205-1208.

Smullin DH, Skilling SR, Larson AA (1990) Interactions between substance $P$, calcitonin gene-related peptide, taurine and excitatory amino acids in the spinal cord. Pain 42:93-101.

Soter NA, Lewis RA, Corey EJ, Austen KF (1983) Local effects of synthetic leukotrienes $\left(\mathrm{LTC}_{4}, \mathrm{LTD}_{4}, \mathrm{LTE}_{4}\right.$, and $\left.\mathrm{LTB}_{4}\right)$ in human skin. J Invest Dermatol 80:115-119.

Stein C, Millan MJ, Shippenberg TS, Herz A (1988) Peripheral effect of fetanyl upon nociception in inflamed tissue of the rat. Neurosci Lett 84:225-228.

Stein C, Millan MJ, Shippenberg TS, Peter K, Herz A (1989) Peripheral opioid receptors mediating antinociception in inflammation. Evidence for involvement of $\mathrm{mu}$, delta and kappa receptors. J Pharmacol Exp Ther 248:1269-1275.

Stein C, Hassan AHS, Przewlocki R, Gramsch C, Klaus P, Herz A (1990) Opioids from immunocytes interact with receptors on sensory nerves to inhibit nociception in inflammation. Proc Natl Acad Sci USA 87:5935-5939.

Stein C, Comisel K, Haimerl E, Yassouridis A, Lehrberger K, Herz A, Peter K (1991) Analgesic effect of intraarticular morphine after arthroscopic knee surgery. N Engl J Med 325:1123-1126.

Suarez-Roca H, Maixner W (1992) Morphine produces a multiphasic effect on the release of substance $P$ from rat trigeminal nucleus slices by activating different opioid receptor subtypes. Brain Res 579:195203.

Suarez-Roca H, Abdullah L, Zuniga J, Madison S, Maixner W (1992) Multiphasic effect of morphine on the relcase of substancc $P$ from rat trigeminal nucleus slices. Brain Res 579:187-194.

Taiwo YO, Levine JD (1988) Characterization of the arachidonic acid metabolites mediating bradykinin and noradrenaline hyperalgesia. Brain Res 458:402-406.

Taiwo YO, Levine JD (1990) Direct cutaneous hyperalgesia induced by adenosine. Neuroscience 38:757-762.

Taiwo YO, Levine JD (1991a) Further confirmation of the role of adenyl cyclase and of cAMP-dependent protein kinase in primary afferent hyperalgesia. Neuroscience 44:131-135.

Taiwo YO, Levine JD (1991b) Kappa- and delta-opioids block sympathetically dependent hyperalgesia. J Neurosci 11:928-932.

Taiwo YO, Levine JD (1992) Serotinin is a directly-acting hyperalgesic agent in the rat. Neuroscience 48:485-490.

Taiwo YO, Goetzl EJ, Levine JD (1987) Hyperalgesia onset latency suggests a hierarchy of action. Brain Res 423:333-337.

Taiwo YO, Heller PH, Levine JD (1990) Characterization of distinct phospholipases mediating bradykinin and noradrenaline hyperalgesia. Neuroscience 39:523-531.

Taiwo YO, Levine JD, Burch RM, Woo JE, Mobley WC (1991) Hyperalgesia induced in the rat by the amino-tcrminal octapcptide of nerve growth factor. Proc Natl Acad Sci USA 88:5144-5148.

Thoenen H (1972) Catecholamines, pp 813-844. Berlin: Springer.

Traub RJ, Solodkin A, Ruda MA (1989) Calcitonin gene-related peptide immunoreactivity in the cat lumbosacral spinal cord and the effects of multiple dorsal rhizotomies. J Comp Neurol 287:225-237.

Tuchscherer MM, Seybold VS (1985) Immunohistochemical studies of substance $P$, cholecystokinin-octapeptide and somatostatin in dorsal root ganglia of the rat. Neuroscience 14:593-605.

Tuchscherer MM, Knox C, Seybold VS (1987) Substance P and cholecystokinin-like immunoreactive varicosities in somatosensory and autonomic regions of the rat spinal cord: a quantitative study of coexistence. J Neurosci 7:3984-3995.

Urban L, Randic M (1984) Slow excitatory transmission in rat dorsal horn: possible mediation by peptides. Brain Res 290:336-341.

Wakisaka S, Kajander KC, Bennett GJ (1991) Increased neuropeptide Y (NPY)-like immunoreactivity in rat sensory neurons following peripheral axotomy. Neurosci Lett 124:200-203.

Waksman G, Hamel E, Fournic-Zaluski MC, Roques BP (1986) Autoradiographic comparison of the distribution of the neutral endopeptidase enkephalinase and of the mu and delta opioid receptors in rat brain. Proc Natl Acad Sci USA 83:1523-1527.

Wall PD, Fitzgerald M (1982) If substance P fails to fulfill the criteria as a neurotransmitter in somatosensory afferents, what might be its function? In: Substance P in the nervous system (Porter R, O'Connor M, eds), pp 249-266. London: Pitman.

Wall PD, Fitzgerald M, Gibson SJ (1981) The response of rat spinal cord cells to unmyelinated afferents after peripheral nerve section and after changes in substance $P$ levels. Neuroscience 6:2205-2215.

Watkins LR, Kinscheck IB, Mayer DJ (1984) Potentiation of opiate analgesia and apparent reversal of morphine tolerance by proglumide. Science 224:395-396.

Weihe E, Nohr D, Millan MJ, Stein C, Muller S, Gramsch C, Herz A (1988) Peptide neuroanatomy of adjuvant-induced arthritic inflammation in rats. Agents Actions 25:255-259.

Werz MA, MacDonald RL (1983) Opioid peptides selective for muand delta-opiate receptors reduce calcium-dependent action potential duration by increasing potassium conductance. Neurosci Lett 42:173178.

Whalley ET, Clegg S, Steward JM, Vavrek RJ (1989) Antagonism of the analgesic action of bradykinin on the human blister base. Adv Exp Med Biol 247A:261-268.

White DM, Helme RD (1985) Release of substance P from peripheral nerve terminals following electrical stimulation of the sciatic nerve. Brain Res 336:27-31.

Wiertelak EP, Maier SF, Watkins LR (1992) Learning to activate CCK antianalgesia: light cues abolish morphine analgesia. Science 256:830833.

Wiesenfeld-Hallin Z (1986a) Somatostatin and calcitonin gene-related peptide synergistically modulate spinal sensory and reflex mechanisms in the rat: behavioral and electrophysiological studies. Neurosci Lett 67:319-323.

Wiesenfeld-Hallin Z (1986b) Substance P and somatostatin modulate spinal cord excitability via physiologically different sensory pathways. Brain Res 372:172-175.

Wiesenfeld-Hallin Z, Hökfelt T, Lundberg JM, Forssmann WG, Reinecke M, Tschopp FA, Fischer JA (1984) Immunoreactive calcitonin gene-related peptide and substance $P$ coexist in sensory neurons to the spinal cord and interact in spinal behavioral responses of the rat. Neurosci Lett 52:199-204.

Wiesenfeld-Hallin Z, Villar MJ, Hökfelt T (1988) Intrathecal galanin at low doses increases spinal refex excitability in rats more to thermal than mechanical stimuli. Exp Brain Res 71:663-666.

Wiesenfeld-Hallin Z, Xu XJ, Villar MJ, Hökfelt T (1989) The effect 
of intrathecal galanin on the flexor reflex in rat: increased depression after sciatic nerve section. Neurosci Lett 105:149-154.

Wiesenfeld-Hallin Z, Xu XJ, Villar MJ, Hökfelt T (1990) Intrathecal galanin potentiates the spinal analgesic effect of morphine: electrophysiological and behavioural studies. Neurosci Lett 109:217-221.

Willcockson WS, Chung JM, Hori Y, Lee KH, Willis WD (1984) Effects of iontophoretically released peptides on primate spinothalamic tract cells. J Neurosci 4:741-750.

Woolf C, Wiesenfeld-Hallin Z (1986) Substance P and calcitonin generelated peptide synergistically modulate the gain of the nociceptive flexor withdrawal reflex in the rat. Neurosci Lett 66:226-230.

Wuster M, Schultz R, Herz A (1981) Multiple opiate receptors in peripheral tissuc preparations. Biochem Pharmacol 30:1883-1887.

Xu XJ, Wiesenfeld-Hallin Z, Villar MJ, Hökfelt T (1989) Intrathecal galanin antagonizes the facilitatory effect of substance $P$ on the nociceptive flexor reflex in the rat. Acta Physiol Scand 137:463-464.

Xu XJ, Wiesenfeld-Hallin Z, Hökfelt T (1991) Intrathecal galanin blocks the prolonged increase in spinal cord flexor reflex excitability induced by conditioning stimulation of unmyelinated muscle afferents in the rat. Brain Res 541:350-353.

Yaksh TL (1988) Substance P release from knee joint afferent terminals: modulation by opioids. Brain Res 458:319-324.

Yaksh TL, Jessell TM, Gamse R, Mudge AW, Leeman SE (1980) Intrathecal morphine inhibits substance $P$ release from mammalian spinal cord in vivo. Nature 286:155-157.

Yaksh TL, Michener SR, Bailey JE, Harty GJ, Lucas DL, Nelson DK,
Roddy DR, Go VLW (1988) Survey of distribution of substance P, vasoactive intestinal polypeptide, cholecystokinin, neurotensin, metenkephalin, bombesin and PHI in the spinal cord of cat, dog, sloth and monkey. Peptides 9:357-372.

Yamamoto T, Yaksh TL (1991) Stereospecific effects of a nonpeptidic NK1 selective antagonist, CP-96,345: antinociception in the absence of motor dysfunction. Life Sci 49:1955-1963.

Yokota Y, Sassai Y, Tanaka K, Fujiwara T, Tsuchida K, Shigemoto R, Kakizuka A, Ohkubo H, Nakanishi S (1989) Molecular characterization of a functional cDNA for rat substance $P$ receptor. $J$ Biol Chem 264:17649-17652.

Yonehara N, Shibutani T, Tsai HY, Inoki R (1986) Effects of opioids and opioid peptidc on the relcasc of substance P-like matcrial induced by tooth pulp stimulation in the trigeminal nucleus caudalis of the rabbit. Eur J Pharmacol 129:209-216.

Yoshimura M, North RA (1983) Substantia gelantinosa neurones hyperpolarised in vitro by enkephalin. Nature 305:529-530.

Young WS, Wamsley JK, Zarbin MA, Kuhar MJ (1980) Opiate receptors undergo axonal flow. Science 210:76-77.

Zajac J-M, Lombard M-C, Peschanski M, Besson J-M, Roques BP (1989) Autoradiographic study of mu and delta opioid binding sites and neutral endopeptidase-24,11 in rat after dorsal root rhizotomy. Brain Res 477:400-403.

Zurawski G, Benedik M, Kamp BJ, Abrams JS, Zurawski SM, Lee FD (1986) Activation of mouse T-helper cells induces abundant preproenkephalin mRNA synthesis. Science 232:772-775. 